\title{
Electrocatalytic oxidation of oxalic and oxamic acids in aqueous media at carbon nanotube modified electrodes.
}

\author{
M. Ferreira ${ }^{1}$, M.F. Pinto ${ }^{1}$, O.S.G.P. Soares ${ }^{2}$, M.F.R. Pereira ${ }^{2}$, J.J.M. Órfão ${ }^{2}$, J.L \\ Figueiredo $^{2}$, I.C. Neves ${ }^{1}$, A.M. Fonseca ${ }^{1}$, P. Parpot $^{1}$ \\ ${ }^{1}$ Centro de Química, Departamento de Química, Escola de Ciências, Universidade do \\ Minho, Campus Gualtar, 4710-057, Braga, Portugal \\ ${ }^{2}$ Laboratório de Catálise e Materiais (LCM), Laboratório Associado LSRE/LCM, \\ Departamento de Engenharia Química, Faculdade de Engenharia, Universidade do \\ Porto, Rua Dr. Roberto Frias, 4200-465 Porto, Portugal
}

\begin{abstract}
The electrochemical oxidation of oxalic and oxamic acids on multiwalled carbon nanotubes $(\mathrm{CNT})$ and on monometallic $(\mathrm{Pd}$ and $\mathrm{Pt})$ and bimetallic $(\mathrm{Pd}-\mathrm{Cu}, \mathrm{Pt}-$ $\mathrm{Cu}$ ) catalysts supported on multiwalled carbon nanotubes was investigated using cyclic voltammetry. The electrodes were prepared by dispersion of the catalytic material on Toray carbon (CT) using a Nafion/water solution. The kinetic parameters of the reactions were determined using cyclic voltammetry. Modification of Toray carbon electrode with carbon nanotubes enables the oxidation of oxalic and oxamic acids in the solvent stability region. The highest oxidation current densities were observed for the $\mathrm{Pt}-\mathrm{Cu} / \mathrm{CNT} / \mathrm{CT}$ electrode in $0.1 \mathrm{M} \mathrm{NaCl}$. The oxidation potentials for both oxalic and oxamic acids in this case were lower than those observed with the CNT/CT electrode. The prepared electrocatalysts show good mechanical and chemical stability.
\end{abstract}

Keywords: Multiwalled carbon nanotubes; oxidation; oxalic and oxamic acids; electrocatalysis, surface modification. 


\section{Introduction}

The increasing need for natural sources of drinking water encourages the development of emerging technologies and processes for water remediation. Organic compound concentrations have increased in effluents and can bring serious consequences, such as high risks to public health and the environment. Therefore, monitoring and elimination of the organic pollutants in wastewater is of high importance. Catalysis employing nanostructured materials is one of the methodologies proposed to reach this objective [1].

Carbon nanotubes (CNT) have attracted growing interest due to their exceptional properties, which make them suitable for many applications such as polymer reinforcements for composites or advanced materials for energy storage, electronics and catalysis [2]. Recently, the use of carbon nanotubes in catalysis has attracted growing attention with special focus on environmental applications, including the oxidation of organic compounds in polluted water by catalytic wet oxidation [3-6]. Due to their versatility, high efficiency, easy control, amenability to automation, environment compatibility and cost effectiveness, electrochemical methods are an effective tool for the transformation of toxic organic compounds into nontoxic ones [7-9]. Moreover, there is a growing interest for the use of nanomaterials in electrochemistry, considering their small size and good electrochemical properties [10-13].

An important part of the work on carbon nanotubes in electrochemistry is related to the field of electro-analysis $[14,15]$. Several authors mentioned that the use of CNT as electrode provides an enhancement of the electrochemical properties in comparison to other electrode materials [16-18]. These peculiar characteristics qualify the CNTs as potential electrode materials for the oxidative degradation of organic pollutants in 
wastewater. In this context, the electrocatalytic oxidation of two carboxylic acids, oxalic and oxamic acids at CNT and Metal-CNT (M-CNT) modified electrodes was studied, aiming at the total mineralization of these compounds.

Ink, textile and metal cleaning industries are the major consumers of oxalic acid [19], which is also an intermediate for many compounds in leather tanning, in bleaching of textiles, stepping agent for permanent press resins, etc. The international demand for oxalic acid is around 0.25 million tons per year. Oxalic acid is also produced as byproduct during the oxidative degradation of phenol and phenol derived compounds. Because it binds vital nutrients such as calcium, high amounts of oxalic acid can cause risks for human health. Oxamic acid, in turn, is a degradation product of aniline and aniline type azo dyes. In addition, both acids have been identified among the most important final products in the ozonation of organic compounds in water and wastewater [20].

In this study, the electroreactivity of oxalic and oxamic acids at CNT and at two monometallic ( $\mathrm{Pd}$ and $\mathrm{Pt}$ ) and two bimetallic $(\mathrm{Pd}-\mathrm{Cu}, \mathrm{Pt}-\mathrm{Cu})$ catalysts supported on CNT was studied in aqueous media using cyclic voltammetry $(\mathrm{CV})$.

\section{Experimental}

\subsection{Chemicals and reagents}

A commercial multiwalled carbon nanotube sample Nanocyl-3100 (sample CNT) was obtained from Nanocyl S.A. The metal precursors $\left(\mathrm{H}_{2} \mathrm{PtCl}_{6}, \mathrm{PdCl}_{2}, \mathrm{Cu}\left(\mathrm{NO}_{3}\right)_{2}\right)$ required for the preparation of the M-CNT samples were purchased from Aldrich. The preparation of modified electrodes was performed using the process described in our previous work [21]. The supporting electrolytes were prepared with ultrapure water (18 $\mathrm{M} \Omega \mathrm{cm}$, Barnsted E-pure system) and sodium chloride (Panreac, $99.5 \%$ ), sodium 
carbonate anhydrous (Panreac, $99.8 \%$ ) and sodium bicarbonate (Panreac, $98 \%$ ). Oxalic and oxamic acids were reagent grade and purchased from Sigma-Aldrich. The aqueous solutions of HPLC standards (glyoxylic, glycolic and formic acids) were prepared from Aldrich commercial reagents. Toray carbon was obtained from Quintech.

\subsection{Preparation of carbon nanotubes supported metal catalysts}

The active metals were supported on sample CNT. The two monometallic (Pd and Pt) samples were prepared by the incipient wetness method, and the bimetallic ( $\mathrm{Pd}-\mathrm{Cu}, \mathrm{Pt}-$ $\mathrm{Cu}$ ) samples by co-impregnation with aqueous solutions of the corresponding metal precursors $\left(\mathrm{H}_{2} \mathrm{PtCl}_{6}, \mathrm{PdCl}_{2}\right.$ and $\left.\mathrm{Cu}\left(\mathrm{NO}_{3}\right)_{2}\right)$. After impregnation, the samples were dried at $100{ }^{\circ} \mathrm{C}$ for $24 \mathrm{~h}$. The samples were calcined under nitrogen flow at $200{ }^{\circ} \mathrm{C}$ for $1 \mathrm{~h}$ and reduced at $200{ }^{\circ} \mathrm{C}$ under hydrogen flow for $3 \mathrm{~h}$. A nitrogen flow was used during cooling till room temperature. The contents of noble metal and copper were always $1 \%$ wt. The samples were characterized using different techniques: temperature programmed reduction (TPR), transmission electron microscopy (TEM), and X-ray photoelectron spectroscopy (XPS), as determined in a previous work [22].

2.3. Preparation of carbon nanotubes and metal-carbon nanotube modified electrodes

For the preparation of modified electrodes, $2 \mathrm{mg}$ of CNT or M-CNT were dissolved in a Nafion/water solution $(120 \mu \mathrm{L}$ Nafion/120 $\mu \mathrm{L}$ ultra pure water). The resulting solutions were homogenized using an ultrasound bath and deposited on a Toray carbon paper with an area of $2 \times 2 \mathrm{~cm}^{2}$. Finally the Toray carbon paper was glued to the platinum electrode using conductive carbon cement and dried at room temperature during $24 \mathrm{~h}$. 


\subsection{Electrochemical Setup}

The voltammetric study was performed in a thermostated three-electrode glass cell and a two-compartment glass cell separated by an ion exchange membrane (Nafion 417). A tap was introduced into the Luggin bridge in order to establish the contact between the reference and the electrolyte solutions without any contamination of the later by the ions of the reference electrode solution. A saturated calomel electrode and a platinum foil (99.95\%) were used as reference and counter electrode, respectively. Before each experiment, the solutions were deaerated with ultra-pure nitrogen (U Quality from Air Liquide) and the nitrogen stream was maintained over the solution during the measurements. The electrochemical instrumentation consists of a potentiostat/galvanostat from Amel Instruments coupled to a microcomputer through an AD/DA converter. The Labview software (National Instruments) and a PCI-MIO-16E-4 I/O module were used for generating and applying the potential program as well as acquiring data, such as current intensities.

\subsection{Product Analysis}

The quantitative analysis of reaction products was performed using two chromatographic set-ups: high performance liquid chromatography (HPLC) using an isocratic pump and a double on line detection including an UV-Vis detector and refractometer, and ionic chromatography (IC, Dionex) using a conductivity detector. The product partition was carried out in ion exchange columns: Aminex HPX-87 H from Biorad for HPLC and AS11-HC from Dionex for IC.

\section{Results and Discussion:}


3.1. Oxidation of oxalic and oxamic acids on carbon nanotube modified Toray carbon electrodes

3.1.1 Electrochemical behavior of oxalic and oxamic acids on modified electrodes

The electroreactivity of oxalic and oxamic acids at CNT/CT was investigated in $0.10 \mathrm{~mol} \mathrm{dm}^{-3} \mathrm{NaCl}$ and carbonate buffer (pH 10).

In order to determine the effect of the carbon nanotubes on the oxidation of oxalic and oxamic acids, the electroreactivity of these compounds was first studied at a non modified Toray carbon electrode. Figure 1 gives the corresponding voltammograms in $0.10 \mathrm{~mol} \mathrm{dm}{ }^{-3} \mathrm{NaCl}$ and in $\mathrm{NaHCO}_{3} / \mathrm{Na}_{2} \mathrm{CO}_{3}$ buffer media in absence and in presence of oxalic acid.

No oxidation peak was noticed after the addition of aliphatic acids, both in acidic and alkaline media; the only difference between the voltammograms in the presence of oxalic and oxamic acids and those obtained in supporting electrolyte media being the very low oxidation current intensities observed in a potential region close to the solvent oxidation. One reduction peak was noticed in acidic and alkaline media during the negative variation of potential, at respectively -0.6 and $-0.5 \mathrm{~V} v s$. SCE.

The voltammograms of CNT modified Toray carbon electrodes in $0.10 \mathrm{~mol} \mathrm{dm}{ }^{-3}$ $\mathrm{NaCl}$, and in $\mathrm{NaHCO}_{3} / \mathrm{Na}_{2} \mathrm{CO}_{3}$ buffer media in the presence and absence of oxalic and oxamic acids are shown in Figure 2 . The solutions of $0.05 \mathrm{~mol} \mathrm{dm}^{-3}$ carboxylic acids prepared with $0.10 \mathrm{~mol} \mathrm{dm}^{-3} \mathrm{NaCl}$ and $\mathrm{NaHCO}_{3} / \mathrm{Na}_{2} \mathrm{CO}_{3}\left(0.10 \mathrm{~mol} \mathrm{dm}^{-3} / 0.10 \mathrm{~mol} \mathrm{dm}^{-3}\right)$ buffer mixture give $\mathrm{pH}$ values of 2 and 8 respectively. The first remark concerns the hundredfold increase of overall current intensities in supporting electrolyte alone after the deposition of $2 \mathrm{mg} \mathrm{CNT}$ on $\mathrm{CT}$, in comparison to the non-modified CT electrode. This fact can be explained by the important increase of active surface area after the 
deposition of $\mathrm{CNT}$ on $\mathrm{CT}$. For oxalic and oxamic acids in $\mathrm{NaCl}$ medium, besides one oxidation and two reduction peaks, important increases of current intensities are observed near to the anodic and cathodic potential limits of the solvent stability. These increases, observed both during the positive variation of potential starting at $0.7 \mathrm{~V} v s$. SCE, and during the negative variation of potential from $-0.8 \mathrm{~V} v s$. SCE, indicate that the redox processes are accompanied by the oxidation and reduction of the solvent, respectively. These results show that the oxidation of oxalic acid, which probably involves $\mathrm{C}-\mathrm{C}$ bond cleavage, occurs at significantly lower potentials on $\mathrm{CNT}$ than those observed on metals and metal oxides. Considering the efficient polarization of carbon atoms in nano scale, due to the van der Walls forces, these results can be explained by an easier formation of positive surface charge, which can be due to surface oxygen complexes, or to the existence of an electron-rich region. On the basis of these results, and considering that for $1.5<\mathrm{pH}<4.5$, the $\mathrm{HC}_{2} \mathrm{O}_{4}{ }^{-}$monoanion is the predominant form of oxalic acid, the following reaction pathways $[23,24]$ can be suggested at $\mathrm{pH}=2$ :

$$
\begin{aligned}
& \mathrm{HC}_{2} \mathrm{O}_{4}^{-} \rightarrow \mathrm{HC}_{2} \mathrm{O}_{4}^{-}{ }^{-} \text {(ads) } \\
& \mathrm{HC}_{2} \mathrm{O}_{4}^{-}{ }_{(\mathrm{ads})} \rightarrow \mathrm{HCO}_{2(\mathrm{ads})}+\mathrm{CO}_{2}+\mathrm{e}^{-} \\
& \mathrm{HCO}_{2(\mathrm{ads})} \rightarrow \mathrm{CO}_{2}+\mathrm{H}^{+}+\mathrm{e}^{-}
\end{aligned}
$$

The presence of oxalic acid causes a slight increase of overall current densities in alkaline medium (Fig. 2.b) with a maximum at $-0.05 \mathrm{~V}$ vs. SCE $\left(i=0.6 \mathrm{~mA} \mathrm{mg}^{-1}\right)$. During the negative variation of potentials, two reduction peaks appear at $-0.25 \mathrm{~V}$ and at $-1.1 \mathrm{~V}$ vs. SCE. These results, which show that the adsorption of oxalic acid and its subsequent oxidation take place to a lower extent in alkaline medium than those observed in acidic $\mathrm{pH}$ medium, are in agreement with the suggestion concerning the influence of surface charge on adsorption, considering that the uptake is lower in basic conditions because of electrostatic repulsions between the negative surface charge and 
the dianion which is the predominant form at $\mathrm{pH}>6$. The voltammogram recorded in presence of oxamic acid, in $0.1 \mathrm{~mol} \mathrm{dm}^{-3} \mathrm{NaCl}$ (Fig. 2. c), does not show any significant difference compared to the one obtained for oxalic acid. The oxidation of oxamic acid in carbonate buffer can be described by a slight increase of current densities between -1 and $0.5 \mathrm{~V}$ vs. SCE with a maximum at $-0.15 \mathrm{~V} v s$. SCE (Fig 2.d)

The peak potentials and the corresponding current densities for the oxidation of

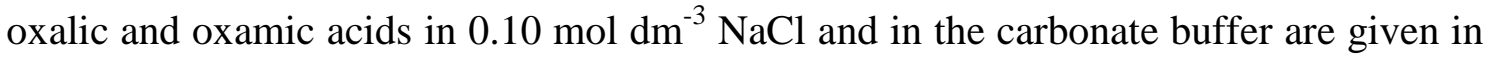
Table 1. These results show that oxalic and oxamic acids exhibit similar electrochemical reactivity at the CNT/CT electrode and display higher oxidation current densities in $\mathrm{NaCl}$ medium than in alkaline medium. These facts can be explained by the lower reactivity of the dianion compared to the monoanion and to undissociated carboxylic acid forms [25].

\subsubsection{Determination of kinetic parameters}

Figure 3 shows $\log j_{p}$ vs. $\log v$ curves for the oxidation of oxalic (3.a) and oxamic acids (3.b) at CNT/CT in $0.10 \mathrm{~mol} \mathrm{dm}^{-3} \mathrm{NaCl}, \mathrm{i}_{\mathrm{p}}$ being the peak current density expressed in $\mathrm{mA} \mathrm{mg}^{-1}$, and $\mathrm{v}$ being the potential sweep rate in $\mathrm{mV} \mathrm{s}^{-1}$. The slopes of the straight lines give information about the limiting step of the reactions for oxalic and oxamic acids (Table 2). Slope values close to 1 , between 5 and $50 \mathrm{mV} \mathrm{s}^{-1}$, and between 5 and $25 \mathrm{mV} \mathrm{s}^{-1}$ for the oxidation of oxalic and oxamic acids, respectively, in the 0.10 mol $\mathrm{dm}^{-3} \mathrm{NaCl}$ medium, indicate that the mechanism is mainly controlled by adsorption. On the other hand, slope values for these two compounds between 0.74 and 0.84, calculated for higher sweep rates (from 50 to $1000 \mathrm{mV} \mathrm{s}^{-1}$ ), show a mixed control (adsorption-diffusion), indicating an increasing influence of the diffusion step in this interval. The peak potentials (E) for the oxidation of oxalic and oxamic acids depend on 
the sweep rate, demonstrating an irreversible electron transfer. According to these results, for the lowest sweep rates, current intensity can be expressed as: $\mathrm{I}=\mathrm{nFA} \mathrm{k}_{\mathrm{f}} \Gamma_{0}$, $\Gamma_{0}$, being the surface coverage and $\mathrm{k}_{\mathrm{f}}$ the heterogeneous rate constant. The number of electrons involved in the rate controlling step for an irreversible process limited by adsorption can be calculated by $\Delta \mathrm{E}_{\mathrm{p}, 1 / 2}=62.5 / \alpha$, the most probable value for the anodic transfer coefficient $(\alpha)$ being 0.5 . The fractional electron number found, which corresponds to 0.5 , is also in agreement with a mechanism involving dissociative adsorption following the fragmentation of the molecule.

The activation energy was calculated from the study of the temperature effect, considering that the activation energy range of a typical diffusion controlled process is lower or equal to about $20 \mathrm{~kJ} \mathrm{~mol}^{-1}$. The effect of temperature was studied from 0 to 50 ${ }^{\circ} \mathrm{C}$ under standardized conditions $\left(50 \mathrm{mV} \mathrm{s}^{-1}, 0.05 \mathrm{~mol} \mathrm{dm}^{-3}\right.$ aliphatic acid in $0.10 \mathrm{~mol}$ $\mathrm{dm}^{-3} \mathrm{NaCl}$ solution). The current densities used in this study were always taken at potentials corresponding to the peak potentials obtained at low sweep rates $\left(5 \mathrm{mVs}^{-1}\right)$, close to the stationary state conditions.

A temperature increase leads to the enhancement of the overall current densities. The values of activation energies $\Delta H^{*}$ were estimated from $\log i_{p}$ vs. 1/T curves using the equation:

$$
\frac{\delta \log i_{p}}{\delta\left(\frac{1}{T}\right)_{E, C}}=-\frac{\Delta H^{*}}{2.3 R}
$$

where $\mathrm{i}_{\mathrm{p}}$ is the current density in $\mathrm{mA} \mathrm{mg}{ }^{-1}$ and $\mathrm{T}$ the absolute temperature in $\mathrm{K}$. The activation energies were below $20 \mathrm{~kJ} \mathrm{~mol}^{-1}$, except that calculated for oxamic acid in $0.10 \mathrm{~mol} \mathrm{dm}^{-3} \mathrm{NaCl}$ medium in the low temperature range which was 32 $\mathrm{kJ} \mathrm{mol}^{-1}$. It can be concluded from these results that, apart from the oxidation of oxamic 
acid in $\mathrm{NaCl}$ medium at lower temperatures, which is limitated by the adsorption, the influence of the diffusion step on reaction kinetics seems to be predominant.

In order to calculate reaction orders, the effect of the concentration of each substrate on current densities, from $5 \times 10^{-4}$ to $0.05 \mathrm{~mol} \mathrm{dm}^{-3}$, at $25^{\circ} \mathrm{C}$, in $0.10 \mathrm{~mol} \mathrm{dm}^{-3}$ $\mathrm{NaCl}$ medium, was investigated. A rough estimation of overall reaction order can be found by measuring the slopes of these curves at very low substrate concentrations. They appear to be nearly 1 for oxalic and oxamic acids. For higher substrate concentrations the slopes for these two carboxylic acids seem to be fractional, indicating the importance of the adsorbed intermediates in reaction kinetics for that range.

\subsubsection{Electrolysis of oxalic acid at carbon nanotube modified Toray carbon}

\section{electrode}

The electrolysis of oxalic acid at the CNT/CT electrode was carried out in $0.10 \mathrm{~mol} \mathrm{\textrm {dm } ^ { - }}$

${ }^{3} \mathrm{NaCl}$ applying a constant current of $0.05 \mathrm{~A}$. No reaction intermediates like formic and acetic acid were detected in the electrolyzed solution, implying that complete transformation of oxalic acid into $\mathrm{CO}_{2}$ occurred. After five hours of electrolysis the quantity of electricity reached $900 \mathrm{C}(18000 \mathrm{~s} x 0.05 \mathrm{~A})$. The experimental number of electrons was calculated from this quantity of electricity as $n=Q / F V$ [oxidized oxalic acid], where V is the volume $(200 \mathrm{~mL})$ of the bulk solution, F the Faraday constant and [oxidized oxalic acid] is the concentration of dicarboxylic acid transformed to the product. The calculated number of electron, which corresponds to 2.2, is in agreement with the transformation of oxalic acid to $\mathrm{CO}_{2}$. The faradic efficiency was calculated using the theoretical and experimental quantities of electricity and corresponds to $92 \%$.

The curves representing the variation of $\log c(t)$ vs. time are given in Figure 4, in order to check the adequacy of the first-order kinetic model. A straight line is observed 
during the first three hours of electrolysis, which proves that the reaction is first order with respect to oxalic acid. The slope of the straight line gives the rate constant, $\mathrm{k}=$ $1.07 \times 10^{-5} \mathrm{~s}^{-1}$.

3.2. Oxidation of oxalic and oxamic acids on Metal-carbon nanotube modified Toray carbon electrodes

3.2.1. Electrochemical behavior of oxalic and oxamic acids at platinum-carbon nanotube and palladium-carbon nanotube modified Toray carbon electrodes

The voltammograms of the $\mathrm{Pt} / \mathrm{CNT} / \mathrm{CT}$ electrode in different $\mathrm{pH}$ media in presence of oxalic and oxamic acids are given in Figure 5. An oxidation and a reduction peak at respectively -0.25 and $-0.45 \mathrm{~V} v$ s. SCE can be distinguished in $0.10 \mathrm{~mol} \mathrm{\textrm {dm } ^ { - 3 }}$ $\mathrm{NaCl}$ medium (Figure 5. a.). These peaks can be attributed to the oxidation and reduction of platinum species on the surface:

$$
\mathrm{Pt}(\mathrm{s})+4 \mathrm{Cl}^{-} \Leftrightarrow \mathrm{PtCl}_{4}{ }^{2-}+2 \mathrm{e}^{-}
$$

The important cathodic currents observed at potentials E $<-0.3 \mathrm{~V} v s$. SCE after the addition of $0.05 \mathrm{~mol} \mathrm{dm} \mathrm{dm}^{-3}$ oxalic acid probably correspond to the reduction of this compound to glyoxylic or glycolic acid, which are strongly adsorbed on platinum. The oxidation of oxalic acid and/or its reduction product take place from this last potential, i. e. $-0.3 \mathrm{~V} v s$. SCE, which corresponds also to the redox potential observed in supporting electrolyte medium alone. Considering that the reduction occurs in region close to the $\mathrm{H}^{+}$adsorption:

$$
\begin{aligned}
& \mathrm{HC}_{2} \mathrm{O}_{4}{ }^{-} \rightarrow \mathrm{HC}_{2} \mathrm{O}_{4}{ }^{-} \text {(ads) } \\
& \mathrm{HC}_{2} \mathrm{O}_{4}{ }^{-}{ }_{(\mathrm{ads})}+2 \mathrm{H}_{(\mathrm{ads})} \rightarrow \mathrm{HC}_{2} \mathrm{O}_{3}{ }^{-}+\mathrm{H}_{2} \mathrm{O}
\end{aligned}
$$

On the other hand, the adsorbed monoanion can be oxidized from $0.3 \mathrm{~V}$ vs. SCE:

$$
\mathrm{HC}_{2} \mathrm{O}_{4}^{-}{ }_{(\mathrm{ads})}+\mathrm{Pt}(\mathrm{II}) \rightarrow \mathrm{Pt}(0)+2 \mathrm{CO}_{2}+\mathrm{H}^{+}
$$


The voltammogram of the $\mathrm{Pt} / \mathrm{CNT} / \mathrm{CT}$ electrode in presence of glycolic acid $\left(0.05 \mathrm{~mol} \mathrm{dm}^{-3}\right)$ in the same conditions is shown in Figure 6. The similarities between this voltammogram and that recorded for oxalic acid confirm the hypothesis of the oxidation of adsorbed glycolic acid during the oxidation of the former compound.

In alkaline medium $(\mathrm{pH} 8)$ the shape of the voltammogram is quite different comparing to those obtained in acidic medium (Figure 5.b). In this case, a hydrogen adsorption/desorption region as well as an $\mathrm{OH}$ adsorption region can be observed in the supporting electrolyte alone, indicating that, after the adsorption of oxalic acid, the reaction may proceed as a surface reaction between adsorbed species:

$$
\begin{aligned}
& 2 \mathrm{OH}^{-} \rightarrow 2 \mathrm{OH}_{(\mathrm{ads})}+2 \mathrm{e}^{-} \\
& \mathrm{C}_{2} \mathrm{O}_{4}{ }^{2-}{ }_{\text {(ads })}+2 \mathrm{OH}_{(\mathrm{ads})} \rightarrow 2 \mathrm{CO}_{3}{ }^{2-}+2 \mathrm{H}^{+}
\end{aligned}
$$

The voltammograms of Pt/CNT/CT in presence of oxamic acid in $0.1 \mathrm{M} \mathrm{NaCl}$ and in carbonate buffer solutions (Figure 5.d and c) are very similar to those observed for oxalic acid. This fact indicates that the $\mathrm{NH}_{2}$ group has no significant effect on the oxidation of this compound.

The voltammograms of the $\mathrm{Pd} / \mathrm{CNT} / \mathrm{CT}$ electrode in $0.10 \mathrm{~mol} \mathrm{dm}^{-3} \mathrm{NaCl}$ and carbonate buffer media in presence of oxalic and oxamic acids are presented in Figure 7. In contrast to the Pt/CNT/CT electrode, no significant change was noticed after the modification of CNT/CT electrode by palladium. Lower oxidation and reduction current intensities were observed in this case, compared to the Pt modified electrode. The oxidation process probably involves a preliminary adsorption step. The following reaction pathways suggested by Casella for oxalic acid [26] may be considered in this case:

$$
\mathrm{Pd}(0)+\mathrm{HC}_{2} \mathrm{O}_{4}^{-} \rightarrow \mathrm{Pd}\left(\mathrm{HC}_{2} \mathrm{O}_{4}{ }^{-}\right)_{\mathrm{ads}}
$$


The oxidation of the adsorbed complex takes place at higher potential in the presence of $\mathrm{Pd}(\mathrm{II})$ species:

$$
\left(\mathrm{HC}_{2} \mathrm{O}_{4}^{-}\right)_{\mathrm{ads}}+\mathrm{Pd}(\mathrm{II}) \rightarrow \mathrm{Pd}(0)+2 \mathrm{CO}_{2}+\mathrm{H}^{+}
$$

The difference between Pt and Pd modified electrodes can be explained by a weaker adsorption of oxalic acid in this last case.

\subsubsection{Electrochemical behavior of oxalic and oxamic acids at bimetallic} electrocatalysts.

The possible synergetic effects due to the presence of a second metal for activating water at lower temperature in order to promote the oxidation of adsorbed $\mathrm{CO}$ species were studied on bimetallic electrodes. Figure 8 shows the voltammograms of Pt$\mathrm{Cu} / \mathrm{CNT} / \mathrm{CT}$ and $\mathrm{Pd}-\mathrm{Cu} / \mathrm{CNT} / \mathrm{CT}$ electrodes in $0.10 \mathrm{~mol} \mathrm{dm}{ }^{-3} \mathrm{NaCl}$ medium in presence of $0.05 \mathrm{~mol} \mathrm{dm}{ }^{-3}$ oxalic acid. An increase of current densities and a slight decrease of oxidation potentials were noticed for the Pt modified electrode while for the Pd-based electrode no significant changes were observed between the voltammograms of bimetallic and monometallic electrodes. The enhanced current densities for Pt/CNT electrocatalyst can be explained by a decrease of the surface deactivation due to the easer oxidation of irreversibly adsorbed species on the electrode surface, like CO. Peak potentials and current densities for these electrodes in two different $\mathrm{pH}$ media are given in Table 3.

3.2.3. Kinetic parameters of the reactions for metal-carbon nanotube modified Toray carbon electrodes

The slope of $\log \left(\mathrm{i} / \mathrm{mA} \mathrm{mg}^{-1}\right)$ vs. $\log \left(\mathrm{v} / \mathrm{mV} \mathrm{s}^{-1}\right)$ curves for the oxidation of oxalic and oxamic acids at monometallic and bimetallic modified electrodes, in different 
$\mathrm{pH}$ media, are given in Table 4. The calculated slope value for the Pt/CNT/CT electrode is close to 0.5 , showing diffusion controlled kinetics for the whole sweep rate interval in this case. These results can be explained by the easy adsorption of oxalic acid on platinum comparing to the $\mathrm{CNT} / \mathrm{CT}$ electrode, placing the diffusion step as the slowest step of the reaction. In order to confirm this result, the activation energy was calculated for the oxidation of oxalic acid on $\mathrm{Pt} / \mathrm{CNT} / \mathrm{CT}$, studying the temperature effect from 0 to $50{ }^{\circ} \mathrm{C}$ under standardized conditions $\left(50 \mathrm{mV} \mathrm{s}^{-1}, 0.05 \mathrm{~mol} \mathrm{dm}^{-3}\right.$ oxalic acid in 0.10 mol dm$\left.{ }^{-3} \mathrm{NaCl}\right)$. The activation energy found for the Pt/CNT/CT electrocatalyst was 13 $\mathrm{kJ} \mathrm{mol}^{-1}$. This value is typically of the order of magnitude expected for a pure diffusion control.

\section{Conclusions}

The oxidation of oxalic and oxamic acids at carbon nanotubes, occurs at lower potentials compared to the metals or metal oxides. Between $0.1 \mathrm{M} \mathrm{NaCl}$ and carbonate buffer media the first one provides highest current densities corresponding to the oxidation of aliphatic acids. Platinum modified electrodes provide higher current densities than $\mathrm{Pd} / \mathrm{CNT}$ electrodes, probably due to the stronger adsorption of the substrate in this case. The addition of copper to Pt/CNT electrocatalyst causes an increase of current intensities and a decrease of oxidation potentials, contrarily to the $\mathrm{Pd} / \mathrm{CNT}$ electrode for which no significant change are noticed. Among all the electrocatalysts studied in this work, a pure diffusion limited reaction kinetic was found only for the Pt/CNT/CT electrode. This result confirms the easier adsorption of organic compounds on platinum. Electrolysis of $0.05 \mathrm{~mol} \mathrm{dm}^{-3}$ oxalic acid on CNT/CT electrode, in $0.10 \mathrm{~mol} \mathrm{dm}^{-3} \mathrm{NaCl}$ medium, permit to transform $45 \%$ of the initial oxalic 
acid into $\mathrm{CO}_{2}$ after 5 hours. All electrocatalysts show chemical and mechanical stability, demonstrating similar activity after several experiments in different $\mathrm{pH}$ media.

\section{Acknowledgements}

Support for this work was provided by the project NANO/NTec-CA/0122/2007 financed by Fundação para a Ciência e a Tecnologia (FCT), Portugal and FEDER, in the context of Programme COMPETE. 


\section{References:}

1. P.C.C. Faria, J.J.M. Órfão, M.F.R. Pereira, Chemosphere, 67 (2007) 809.

2. P. Serp, M. Corrias, P. Kalck, Appl. Catal. A-Gen., 253 (2003) 337.

3. M. F. R. Pereira, J.L. Figueiredo, J.J.M. Orfão, P. Serp, P. Kalck, Y. Kihn, Carbon, 42 (2004) 2807

4. S.M. Alia, G. Zhang, D. Kisailus, D. Li, S. Gu, K. Jensen, Y. Yan, Adv. Funct. Mater. (20) 2010, 3742

5. A.G. Gonçalves, J.L. Figueiredo, J.J.M. Órfão, M.F.R. Pereira, Carbon, 48 (2010) 4369

6. R.P. Rocha, J.P. Sousa, A.M.T. Silva, M.F.R. Pereira, J.L. Figueiredo, Appl. Catal. B, 104 (2011) 330

7. J.D. Rodgers, W. Jedral, N.J. Bunce, Environ. Sci. Technol., 33 (1999) 1453

8. J Iniesta, P.A. Michaud, M. Panizza, G. Cerisola, A. Aldaz, C. Comninellis Electrochim. Acta, 46 (2001) 3573

9. Feng YJ, Li XY, Water Res. 37(2003) 2399

10. S. Yang, R. Yang, G. Li, J. Jun, L. Qu, J. Chem. Sci., 122, (2010) 919

11. Y.Z. Lu, W. Chen, J. Phys. Chem.. C, 114 (2010) 21190

12. R. N. Singh, Anindita, Madhu, J. Solid State Electrochem., 14 (2010) 2113

13. Li W, Zhou W, Li H, Zhou Z, Zhou B, Sun G, Xin Q Electrochim. Acta, 49 (2004) 1045

14. J. J. Gooding, Electrochim. Acta, 50 (2005) 3049

15. Z. Wang J. Liu Q. Liang, Y. Wang, G. Luo, Analyst, 127 (2002) 653

16. M. D. Rubianes, G. A. Rivas, Electrochem. Commun., 5 (2003) 689

17. Y. Zeng, C. Yang, W. Pu, J. Zhang, Food Chem., 114 (2009) 1523. 
18. G. Liu, S. L. Riechers, M. C. Mellen, Y. Lin, Electrochem. Commun., 7 (2005) 1163

19. S. Roy, M. Vashishtha and A. K. Saroha, J. Eng. Sci. Technol. Rev. 3 (1) (2010) 95

20. P.C.C. Faria, J.J.M. Órfão, M.F.R. Pereira, Applied Catalysis B: Environmental, 79 (2008) 237

21. A. M. Fonseca, S. Gonçalves, P. Parpot, I. C. Neves, Phys. Chem. Chem. Phys., 11 (2009) 6308

22. O.S.G.P. Soares, J.J. M. Orfão, M.F. R. Pereira, Ind. Eng. Chem. Res. 2010, 49, 7183

23. C. A. Martinez-Huitle, S. Ferro, A. De Battisti, Electrochim. Acta 49 (2004) 4027.

24. S. A. Sargisyan, Yu. B. Vasil'ev, Elektrokhimiya 18 (1982) 954.

25. M. J. C-Brym, F. Epron, E. Lamy-Pitara, J. Barbier, J of. Electroanal. Chem., 474 (1999) 147

26. I. G. Casella, Electrochim. Acta 44 (1999) 3353. 


\section{Legends of illustrations}

Figure 1. Voltammograms of Carbon Toray (CT) electrode in a) $0.1 \mathrm{M} \mathrm{NaCl}$ and b) $\mathrm{NaHCO}_{3} / \mathrm{Na}_{2} \mathrm{CO}_{3}$ buffer, in the presence and in absence of $0.05 \mathrm{M}$ oxalic acid.

Figure 2. Voltammograms of CNT modified Carbon Toray electrode (CNT/CT) in presence and in absence of $0.05 \mathrm{M}$ oxalic acid, in a) $0.1 \mathrm{M} \mathrm{NaCl}$ b) $\mathrm{NaHCO}_{3} / \mathrm{Na}_{2} \mathrm{CO}_{3}$ buffer, and in presence and in absence of $0.05 \mathrm{M}$ oxamic acid in c) $0.1 \mathrm{M} \mathrm{NaCl}$ and d) $\mathrm{NaHCO}_{3} / \mathrm{Na}_{2} \mathrm{CO}_{3}$ buffer

Figure 3. $\log \mathrm{j} v s . \log \mathrm{v}$ curves for the oxidation of a) $0.05 \mathrm{M}$ oxalic acid and b) $0.05 \mathrm{M}$ oxamic acid on $\mathrm{CNT} / \mathrm{CT}$ electrode in $0.1 \mathrm{M} \mathrm{NaCl}$, at $25^{\circ} \mathrm{C}$

Figure 4. Variation of the concentrations of oxalic acid (a) vs. time during prolonged electrolysis of $0.05 \mathrm{M}$ oxalic acid on the CNT/CT electrode in $0.1 \mathrm{M} \mathrm{NaCl}$ medium.

Figure 5. Voltammograms of Pt/CNT modified Carbon Toray electrode (Pt/CNT/CT) in presence and in absence of $0.05 \mathrm{M}$ oxalic acid, in a) $0.1 \mathrm{M} \mathrm{NaCl}$ and b) $\mathrm{NaHCO}_{3} / \mathrm{Na}_{2} \mathrm{CO}_{3}$ buffer, and in presence and in absence of $0.05 \mathrm{M}$ oxamic acid in c) $0.1 \mathrm{M} \mathrm{NaCl}$ and d) $\mathrm{NaHCO}_{3} / \mathrm{Na}_{2} \mathrm{CO}_{3}$ buffer

Figure 6. Voltammograms of Pt/CNT modified Carbon Toray electrode (Pt/CNT/CT) in $0.1 \mathrm{M} \mathrm{NaCl}$ in presence and in absence of $0.05 \mathrm{M}$ glycolic acid.

Figure 7. Voltammograms of Pd/CNT modified Carbon Toray electrode (Pd/CNT/CT) in presence and in absence of $0.05 \mathrm{M}$ oxalic acid in a) $0.1 \mathrm{M} \mathrm{NaCl}$ and b) $\mathrm{NaHCO}_{3} / \mathrm{Na}_{2} \mathrm{CO}_{3}$ buffer, and in presence and in absence of $0.05 \mathrm{M}$ oxamic acid in c) $0.1 \mathrm{M} \mathrm{NaCl}$ and d) $\mathrm{NaHCO}_{3} / \mathrm{Na}_{2} \mathrm{CO}_{3}$ buffer 
Figure 8. Voltammograms of a) Pt-Cu/CNT modified Carbon Toray electrode (Pt$\mathrm{Cu} / \mathrm{CNT} / \mathrm{CT}$ ) and b) Pd-Cu/CNT modified Carbon Toray electrode (Pd-Cu/CNT/CT), in $0.1 \mathrm{M} \mathrm{NaCl}$, in presence and in absence of $0.05 \mathrm{M}$ oxalic acid. 


\section{Tables}

Table 1. Electrochemical data for the oxidation of oxalic and oxamic acids on the CNT/CT electrode in different $\mathrm{pH}$ media

Table 2. Values of the slopes of the $\log \mathrm{i}=\mathrm{f}(\log \mathrm{v})$ curves for the oxidation of oxalic and oxamic acids on CNT/CT electrode in different $\mathrm{pH}$ media.

Table 3. Electrochemical data for the oxidation of oxalic and oxamic acids on monometallic and bimetallic electrodes in different $\mathrm{pH}$ media

Table 4. Values of the slopes of the $\log \mathrm{i}=\mathrm{f}(\log \mathrm{v})$ curves for the oxidation of oxalic and oxamic acids on monometallic and bimetallic electrodes in different $\mathrm{pH}$ media. 
Table 1.

\begin{tabular}{|c|c|c|c|c|c|}
\hline \multirow[b]{2}{*}{ Compound } & \multirow{2}{*}{$\begin{array}{l}\text { Supporting } \\
\text { electrolyte }\end{array}$} & \multicolumn{2}{|c|}{ Oxidation } & \multicolumn{2}{|c|}{ Reduction } \\
\hline & & $\begin{array}{l}\mathrm{Ep}(\mathrm{Ox}) \\
(\mathrm{V} / \mathrm{SCE})\end{array}$ & $\begin{array}{c}\mathrm{i}(\mathrm{Ox}) \\
\left(\mathrm{mA} \cdot \mathrm{mg}^{-1}\right)\end{array}$ & $\begin{array}{l}\text { Ep(Red) } \\
(\mathrm{V} / \mathrm{SCE})\end{array}$ & $\begin{array}{c}\mathrm{i}(\text { Red }) \\
\left(\mathrm{mA} \cdot \mathrm{mg}^{-1}\right)\end{array}$ \\
\hline \multirow[b]{2}{*}{ Oxalic acid } & $\mathrm{NaCl} 0.1 \mathrm{M}$ & 0.35 & 2.14 & 0.14 & 0.74 \\
\hline & $\begin{array}{c}\mathrm{NaHCO}_{3} / \mathrm{Na}_{2} \mathrm{CO}_{3} \\
\text { buffer }\end{array}$ & -0.09 & 0.55 & -0.28 & 0.36 \\
\hline \multirow{2}{*}{ Oxamic acid } & $\mathrm{NaCl} 0.1 \mathrm{M}$ & 0.35 & 1.94 & $\begin{array}{l}0.11 \\
-0.62\end{array}$ & $\begin{array}{l}1.50 \\
1.67\end{array}$ \\
\hline & $\begin{array}{c}\mathrm{NaHCO}_{3} / \mathrm{Na}_{2} \mathrm{CO}_{3} \\
\text { buffer }\end{array}$ & -0.15 & 0.14 & -0.26 & 0.08 \\
\hline
\end{tabular}


Table 2

\begin{tabular}{|c|c|c|c|c|}
\hline Compound & $\begin{array}{l}\text { Supporting } \\
\text { electrolyte }\end{array}$ & $\begin{array}{l}\text { Sweep rate } \\
\text { range }\left(\mathrm{mV} \mathrm{s}^{-}\right. \\
\left.\left.\mathbf{1}^{-}\right)\right)\end{array}$ & Slope & Limiting step \\
\hline \multirow{3}{*}{ Oxalic acid } & \multirow{2}{*}{$\mathrm{NaCl} 0.1 \mathrm{M}$} & $5-50$ & 1.1 & adsorption \\
\hline & & $50-1000$ & 0.74 & mixed \\
\hline & $\mathrm{NaHCO}_{3} / \mathrm{Na}_{2} \mathrm{CO}_{3}$ & $5-1000$ & 0.78 & mixed \\
\hline \multirow{4}{*}{ Oxamic acid } & \multirow{2}{*}{$\mathrm{NaCl} 0.1 \mathrm{M}$} & $5-25$ & 1.0 & adsorption \\
\hline & & $25-1000$ & 0.80 & mixed \\
\hline & \multirow[t]{2}{*}{$\mathrm{NaHCO}_{3} / \mathrm{Na}_{2} \mathrm{CO}_{3}$} & $5-10$ & 1.2 & adsorption \\
\hline & & $10-1000$ & 0.84 & mixed \\
\hline
\end{tabular}


Table 3

\begin{tabular}{|c|c|c|c|c|}
\hline \multirow[b]{2}{*}{ Product } & \multirow[b]{2}{*}{ Metal } & \multirow{2}{*}{$\begin{array}{l}\text { Supporting } \\
\text { electrolyte }\end{array}$} & \multicolumn{2}{|c|}{ Oxidation } \\
\hline & & & $\begin{array}{c}\mathrm{E}_{\mathrm{p}}(\mathrm{Ox}) \\
(\mathrm{V} / \mathrm{SCE})\end{array}$ & $\begin{array}{c}\mathrm{i}(\mathrm{Ox}) \\
\left(\mathrm{mA} \cdot \mathrm{mg}^{-1}\right)\end{array}$ \\
\hline \multirow{8}{*}{ Oxalic acid } & \multirow{2}{*}{$\mathrm{Pt}$} & $\mathrm{NaCl} 0.1 \mathrm{M}$ & -0.19 & 7.53 \\
\hline & & $\mathrm{NaHCO}_{3} / \mathrm{Na}_{2} \mathrm{CO}_{3}$ & -0.12 & 1.18 \\
\hline & \multirow{2}{*}{$\mathrm{Pt}-\mathrm{Cu}$} & $\mathrm{NaCl} 0.1 \mathrm{M}$ & -0.15 & 11.80 \\
\hline & & $\mathrm{NaHCO}_{3} / \mathrm{Na}_{2} \mathrm{CO}_{3}$ & -0.47 & 0.44 \\
\hline & \multirow{2}{*}{$\mathrm{Pd}$} & $\mathrm{NaCl} 0.1 \mathrm{M}$ & 0.32 & 1.10 \\
\hline & & $\mathrm{NaHCO}_{3} / \mathrm{Na}_{2} \mathrm{CO}_{3}$ & $-0,41$ & 0.64 \\
\hline & \multirow{2}{*}{$\mathrm{Pd}-\mathrm{Cu}$} & $\mathrm{NaCl} 0.1 \mathrm{M}$ & 0.34 & 1.33 \\
\hline & & $\mathrm{NaHCO}_{3} / \mathrm{Na}_{2} \mathrm{CO}_{3}$ & 0.07 & 0.42 \\
\hline \multirow{8}{*}{ Oxamic acid } & \multirow[t]{2}{*}{$\mathrm{Pt}$} & $\mathrm{NaCl} 0.1 \mathrm{M}$ & -0.16 & 5.26 \\
\hline & & $\mathrm{NaHCO}_{3} / \mathrm{Na}_{2} \mathrm{CO}_{3}$ & -0.12 & 0.60 \\
\hline & \multirow[t]{2}{*}{$\mathrm{Pt}-\mathrm{Cu}$} & $\mathrm{NaCl} 0.1 \mathrm{M}$ & -0.17 & 11.7 \\
\hline & & $\mathrm{NaHCO}_{3} / \mathrm{Na}_{2} \mathrm{CO}_{3}$ & -0.06 & 0.33 \\
\hline & \multirow[t]{2}{*}{$\mathrm{Pd}$} & $\mathrm{NaCl} 0.1 \mathrm{M}$ & 0.33 & 1.56 \\
\hline & & $\mathrm{NaHCO}_{3} / \mathrm{Na}_{2} \mathrm{CO}_{3}$ & -0.06 & 1.05 \\
\hline & \multirow[t]{2}{*}{$\mathrm{Pd}-\mathrm{Cu}$} & $\mathrm{NaCl} 0.1 \mathrm{M}$ & 0.36 & 1.27 \\
\hline & & $\mathrm{NaHCO}_{3} / \mathrm{Na}_{2} \mathrm{CO}_{3}$ & 0.04 & 0.55 \\
\hline
\end{tabular}


Table 4

\begin{tabular}{|c|c|c|c|c|c|}
\hline Product & Metal & Supporting electrolyte & Range & Ilog i// $\{\log \mathrm{v}$ & Limiting step \\
\hline \multirow{9}{*}{$\begin{array}{c}\text { Oxalic } \\
\text { acid }\end{array}$} & \multirow{3}{*}{$\mathrm{Pt}$} & $\mathrm{NaCl} 0.1 \mathrm{M}$ & $5-1000$ & 0.40 & diffusion \\
\hline & & \multirow{2}{*}{$\mathrm{NaHCO}_{3} / \mathrm{Na}_{2} \mathrm{CO}_{3}$} & $5-100$ & 0.51 & diffusion \\
\hline & & & $100-1000$ & 0.77 & mixed \\
\hline & $\mathrm{Pt}-\mathrm{Cu}$ & $\mathrm{NaCl} 0.1 \mathrm{M}$ & $5-1000$ & 0.44 & diffusion \\
\hline & \multirow{3}{*}{$\mathrm{Pd}$} & \multirow{2}{*}{$\mathrm{NaCl} 0.1 \mathrm{M}$} & $5-100$ & 1.1 & adsorption \\
\hline & & & $100-1000$ & 0.58 & diffusion \\
\hline & & $\mathrm{NaHCO}_{3} / \mathrm{Na}_{2} \mathrm{CO}_{3}$ & $5-1000$ & 0.81 & mixed \\
\hline & \multirow{2}{*}{$\mathrm{Pd}-\mathrm{Cu}$} & $\mathrm{NaCl} 0.1 \mathrm{M}$ & $5-1000$ & 0.88 & mixed \\
\hline & & $\mathrm{NaHCO}_{3} / \mathrm{Na}_{2} \mathrm{CO}_{3}$ & $5-1000$ & 0.81 & mixed \\
\hline \multirow{7}{*}{$\begin{array}{c}\text { Oxamic } \\
\text { acid }\end{array}$} & \multirow{2}{*}{$\mathrm{Pt}$} & $\mathrm{NaCl} 0.1 \mathrm{M}$ & $5-1000$ & 0.36 & diffusion \\
\hline & & $\mathrm{NaHCO}_{3} / \mathrm{Na}_{2} \mathrm{CO}_{3}$ & $5-1000$ & 0.90 & adsorption \\
\hline & $\mathrm{Pt}-\mathrm{Cu}$ & $\mathrm{NaCl}$ & $5-1000$ & 0.46 & diffusion \\
\hline & \multirow{2}{*}{$\mathrm{Pd}$} & $\mathrm{NaCl}$ & $5-1000$ & 0.92 & adsorption \\
\hline & & $\mathrm{NaHCO}_{3} / \mathrm{Na}_{2} \mathrm{CO}_{3}$ & $5-1000$ & 0.90 & adsorption \\
\hline & \multirow{2}{*}{$\mathrm{Pd}-\mathrm{Cu}$} & $\mathrm{NaCl}$ & $5-1000$ & 0.91 & adsorption \\
\hline & & $\mathrm{NaHCO}_{3} / \mathrm{Na}_{2} \mathrm{CO}_{3}$ & $5-1000$ & 0.97 & adsorption \\
\hline
\end{tabular}




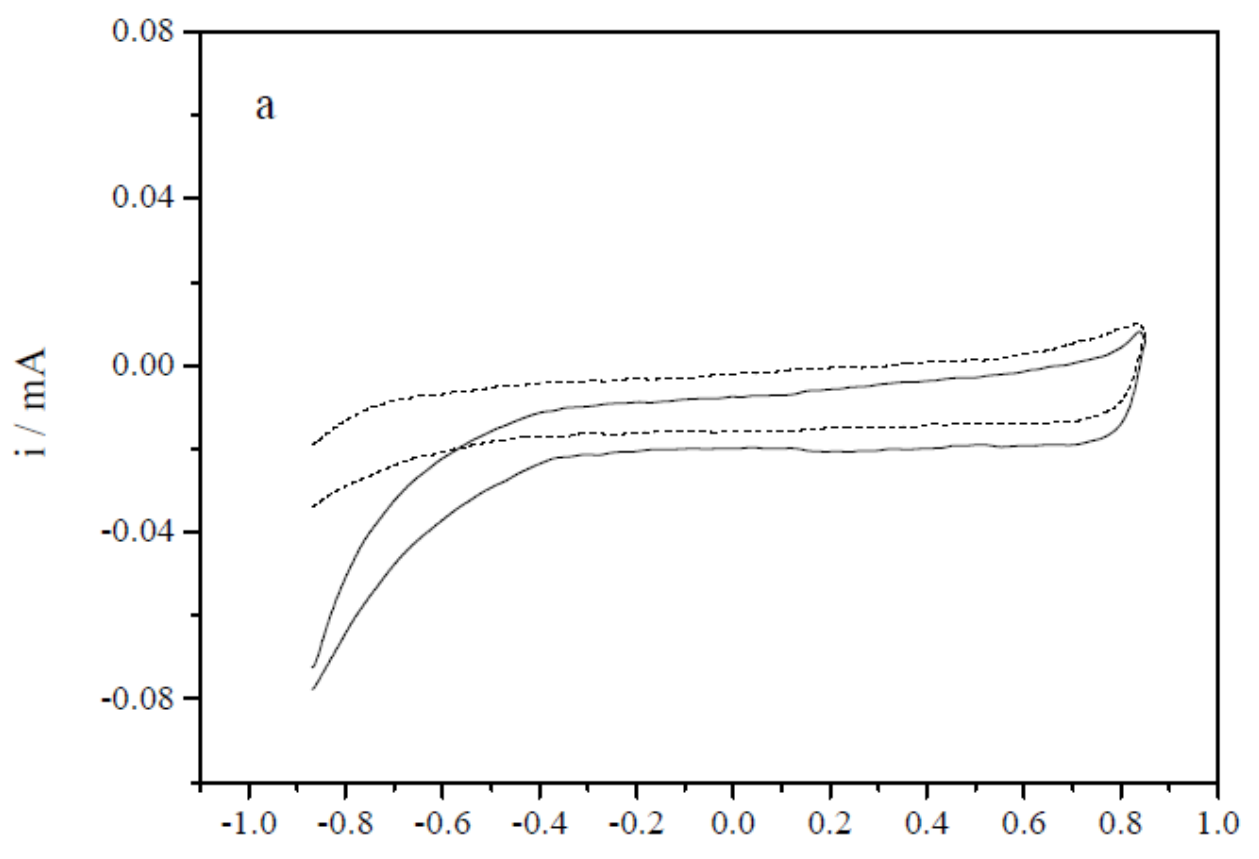

Figure 1a

E vs. SCE/V

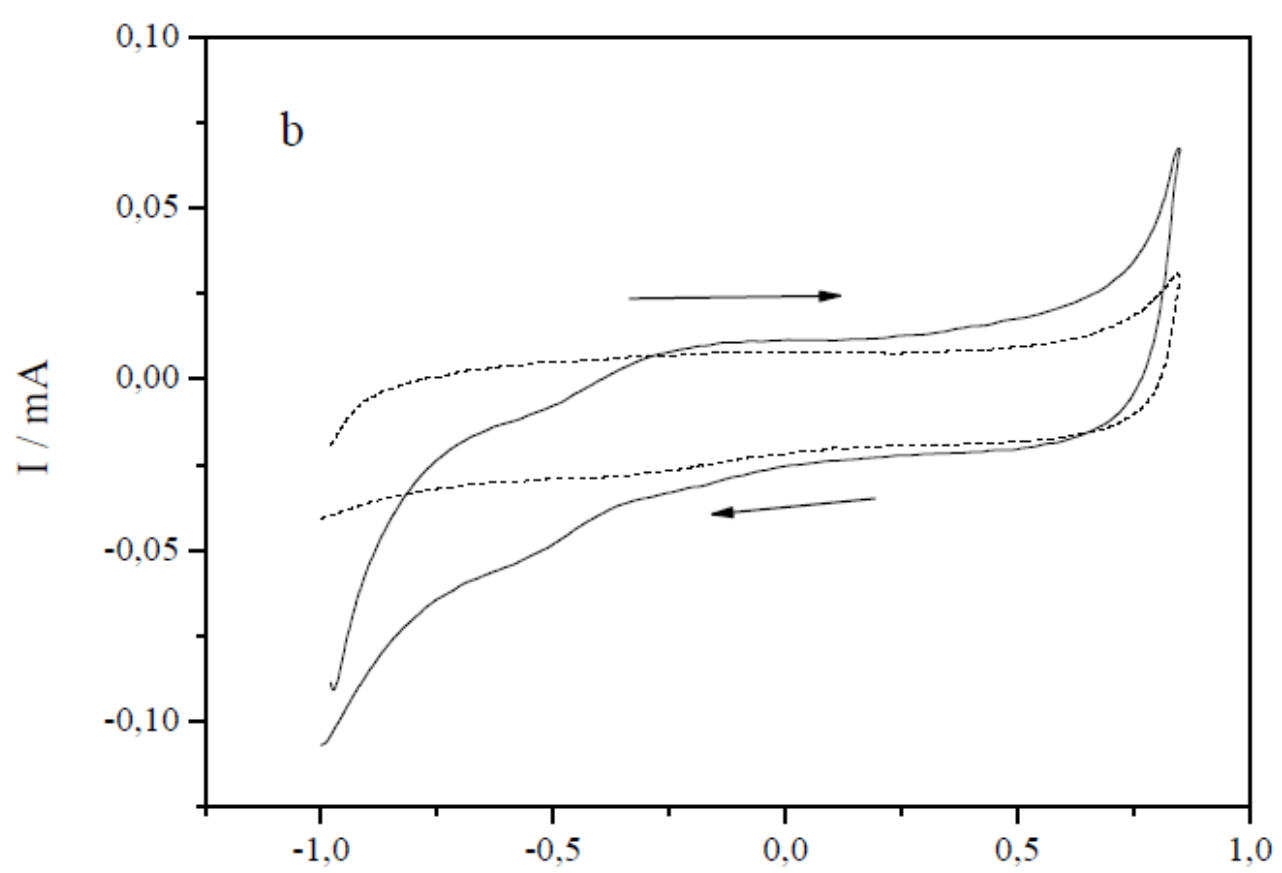

Figure 1b

E vs. SCE/V 


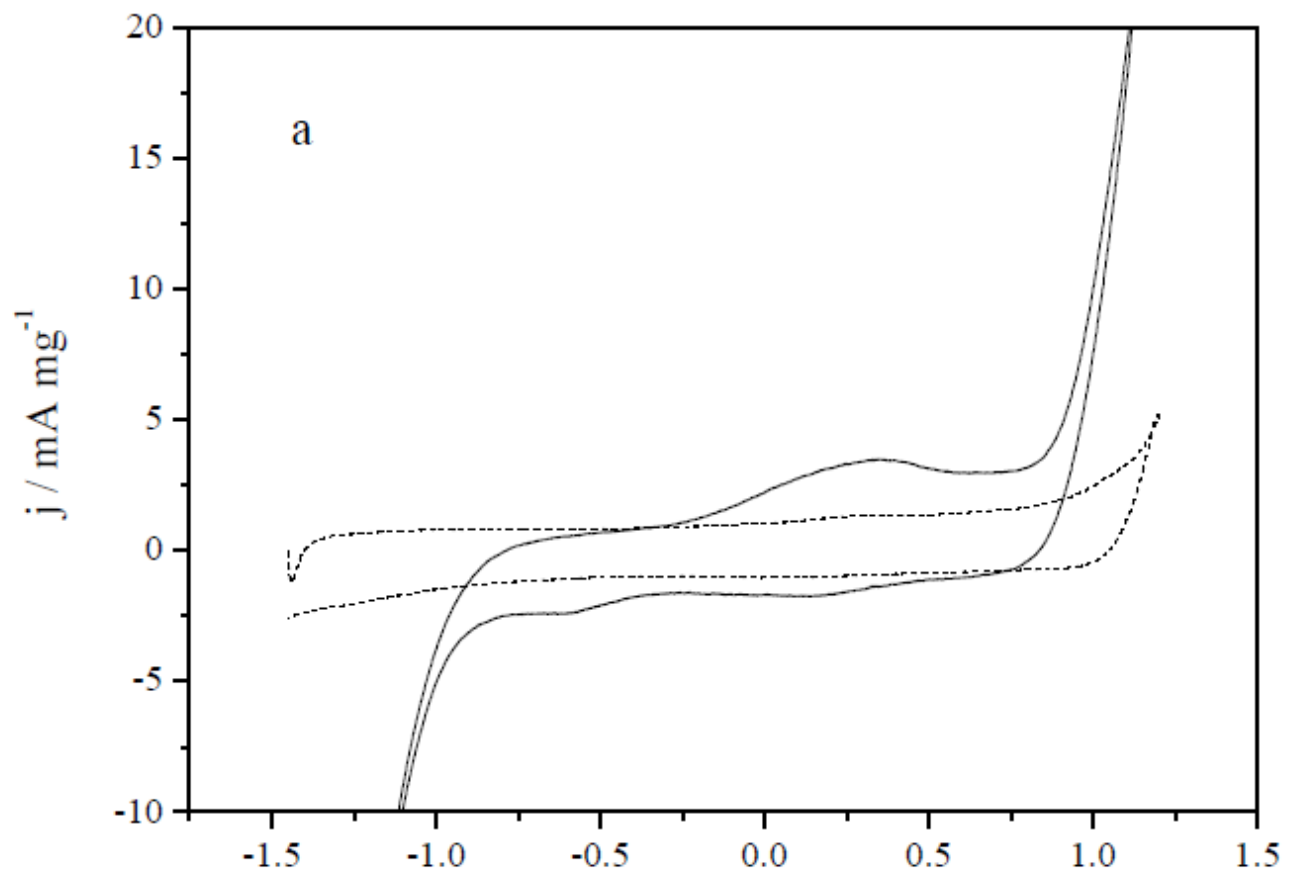

Figure 2. a.

E vs. SCE/V

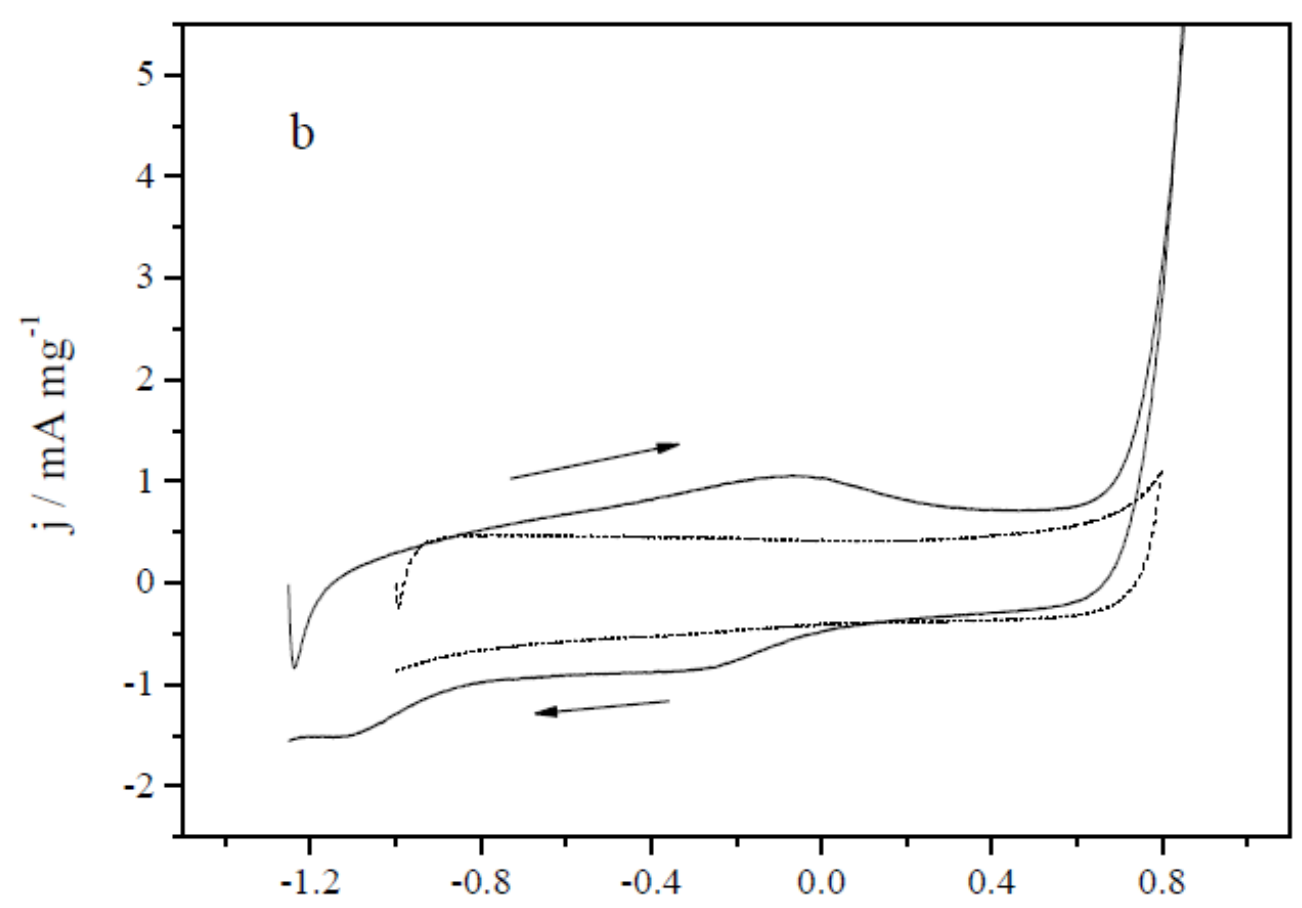

Figure 2.b

Evs. SCE/V 


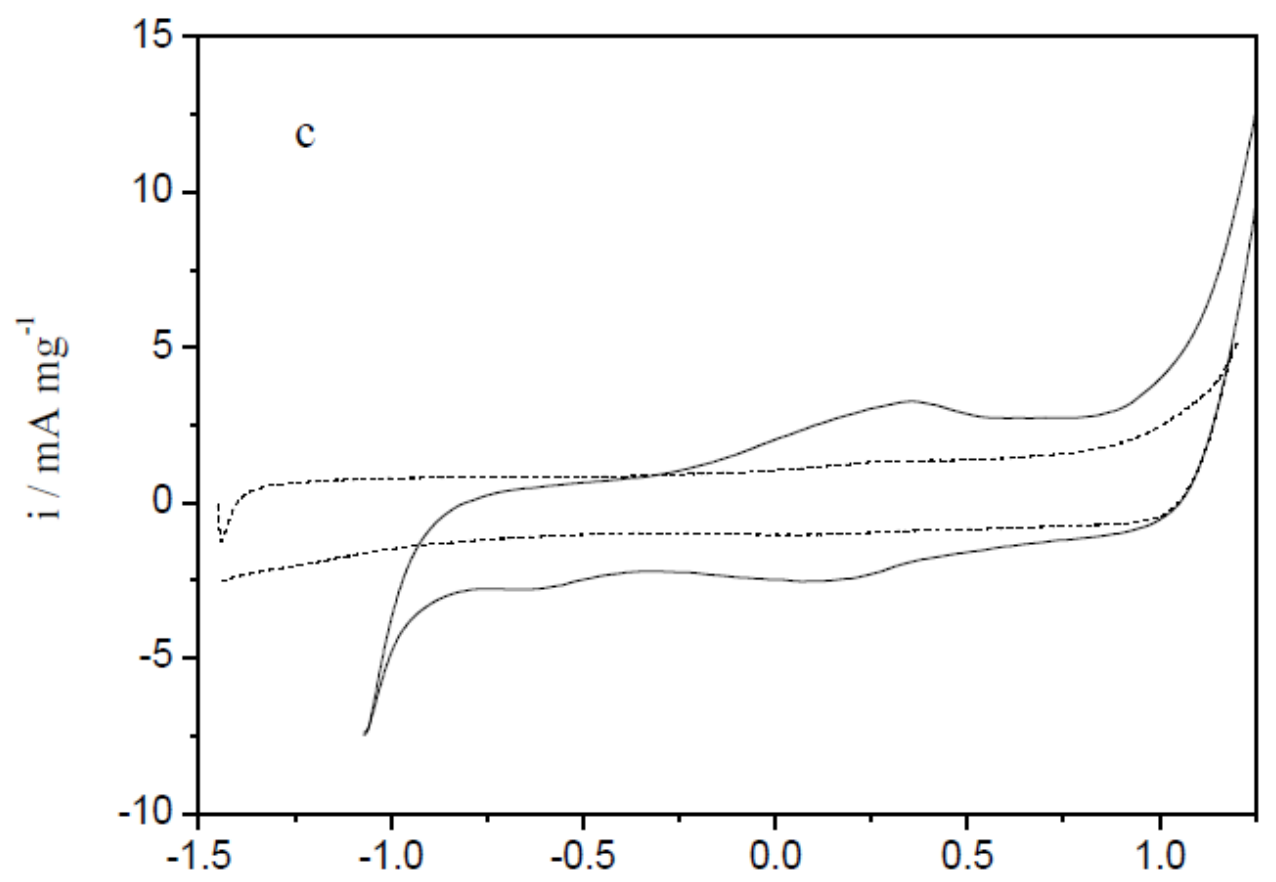

Figure 2. c

E vs. $\mathrm{SCE} / \mathrm{V}$

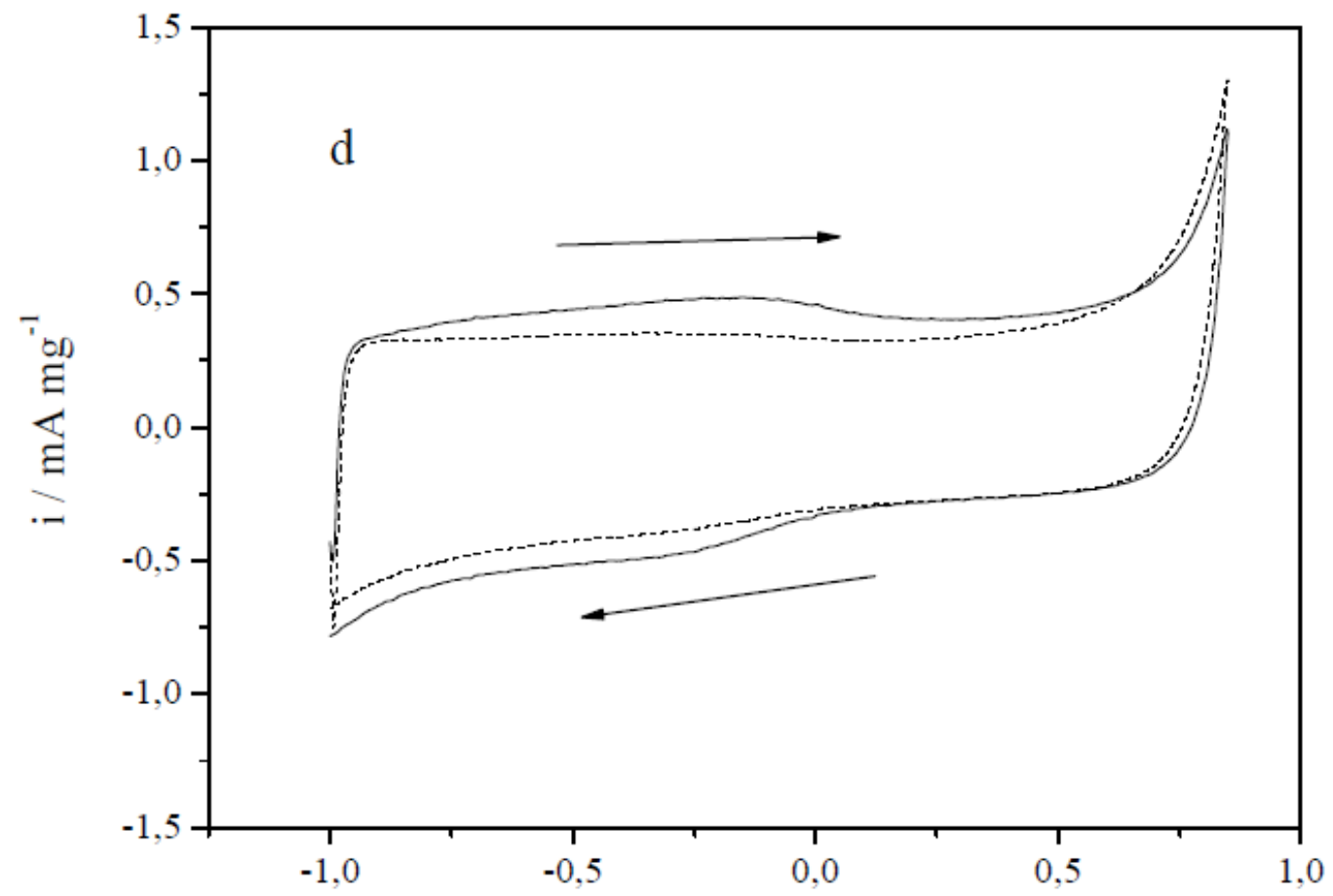

Figure 2.d

Evs. SCE/V 

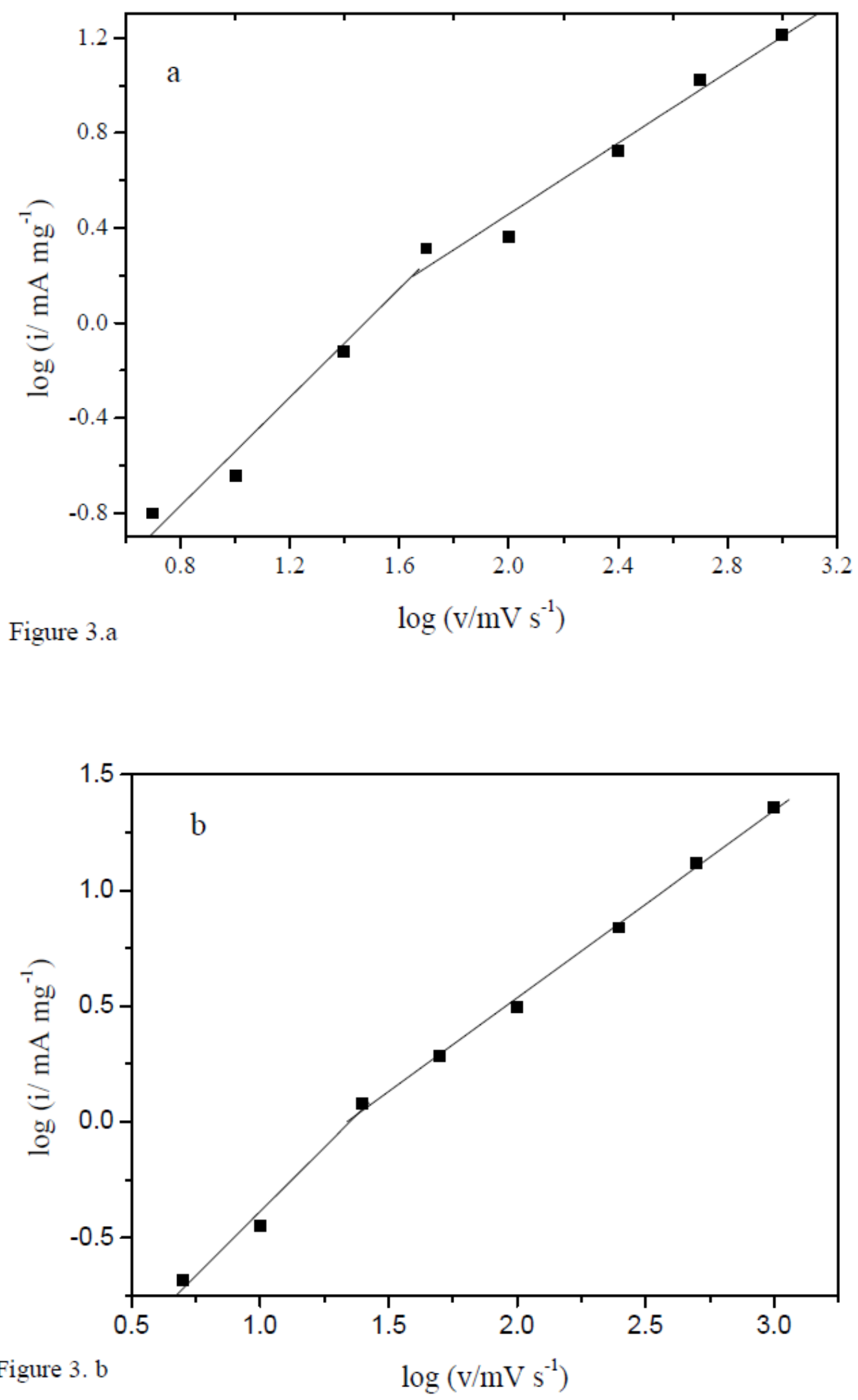


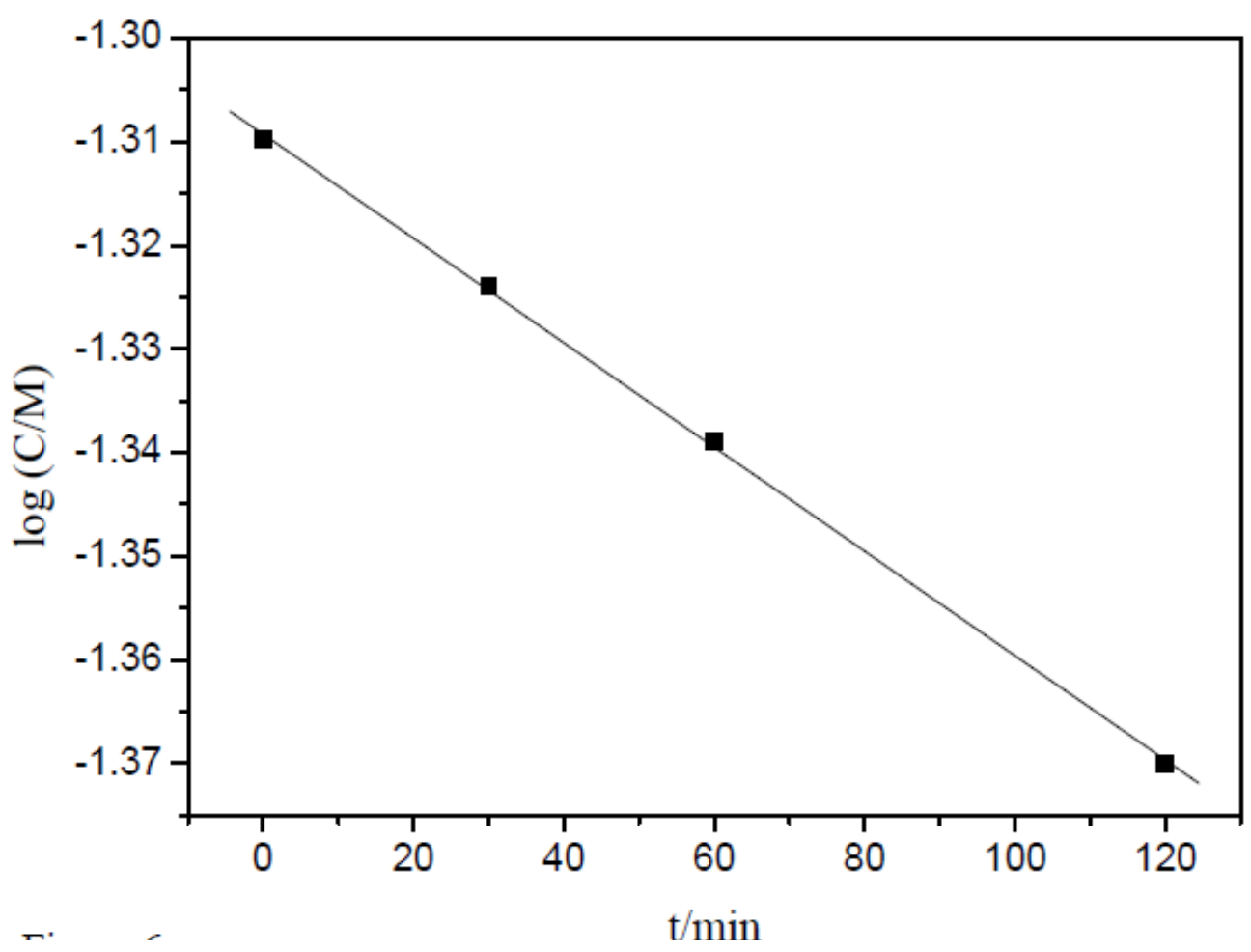

Figure 4

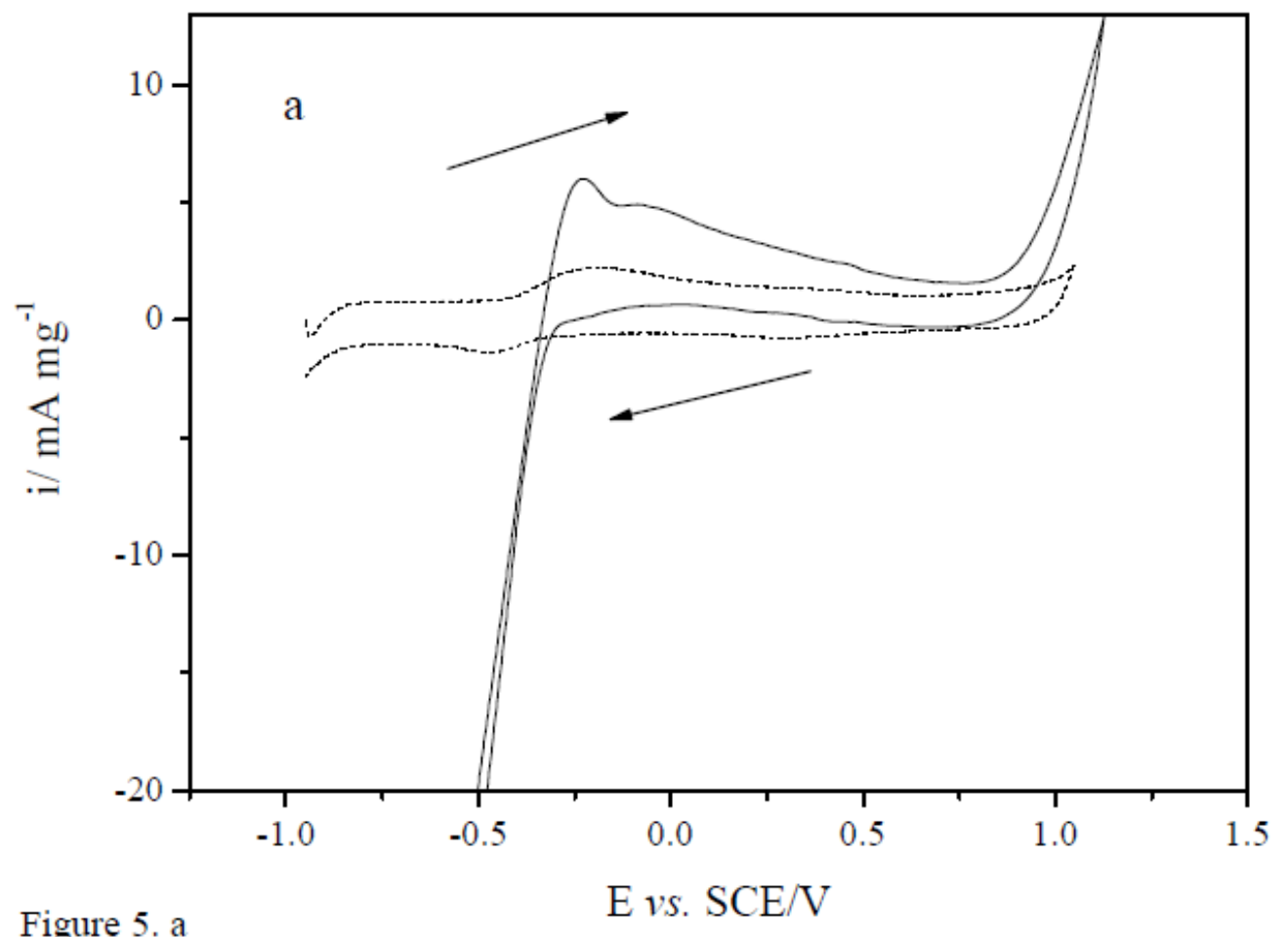




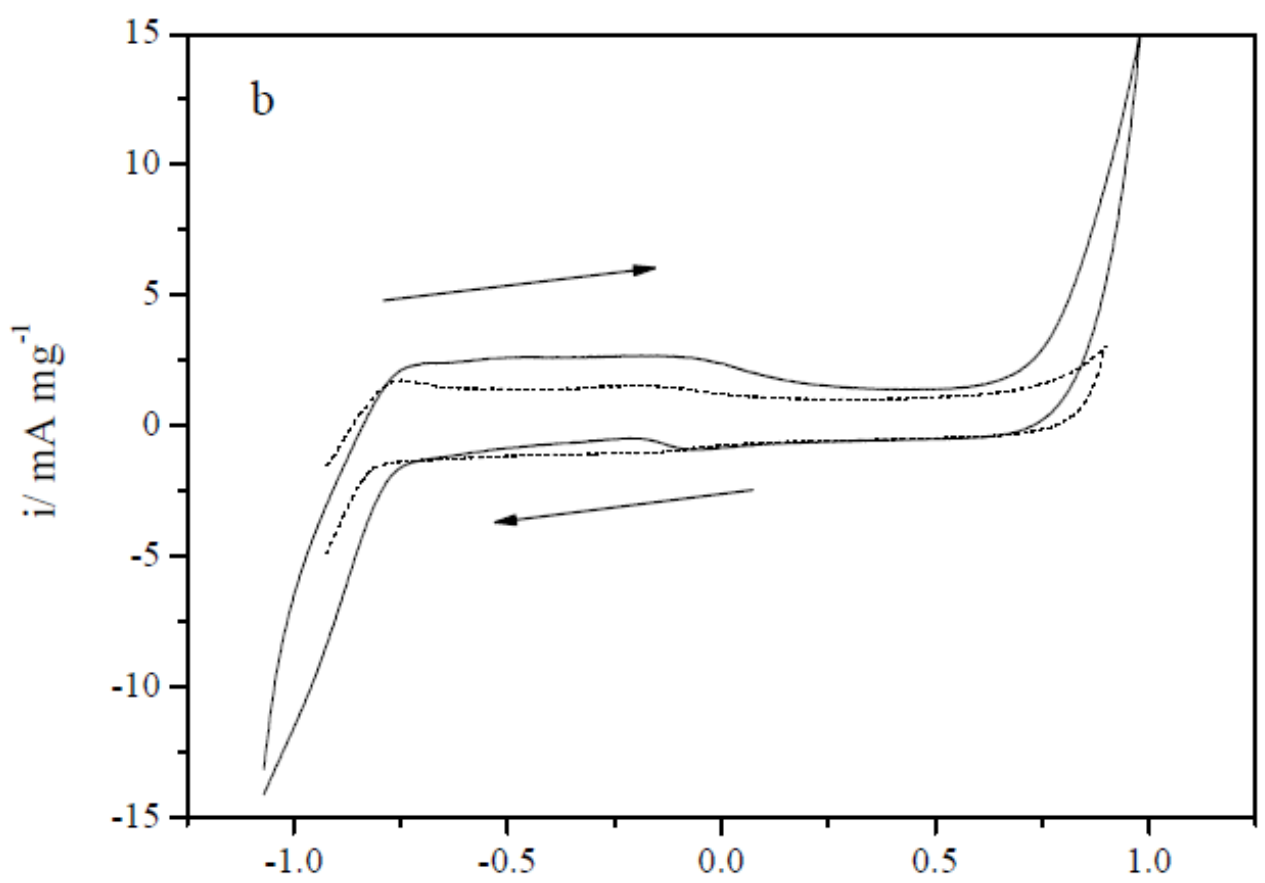

Figure 5. b

E vs. SCE/V

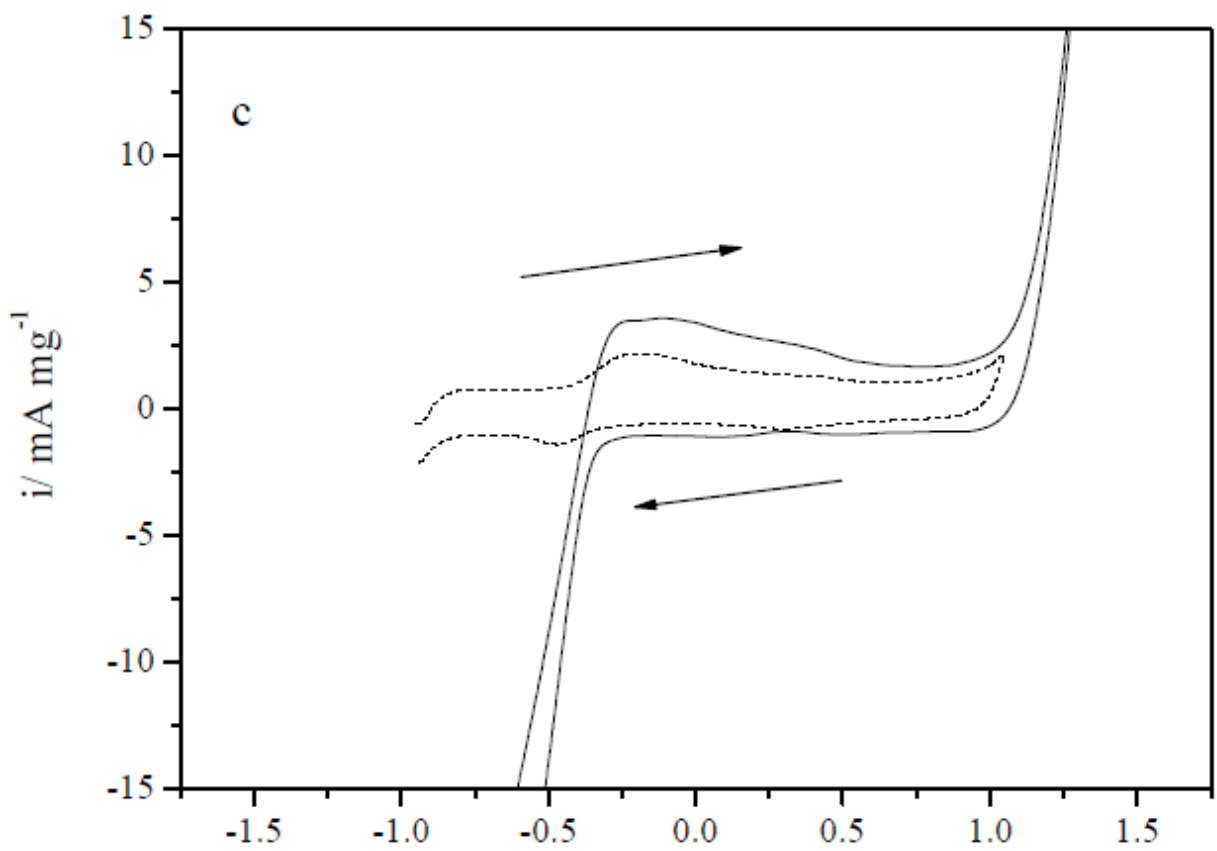

Figure 5.c

Evs. SCE/V 


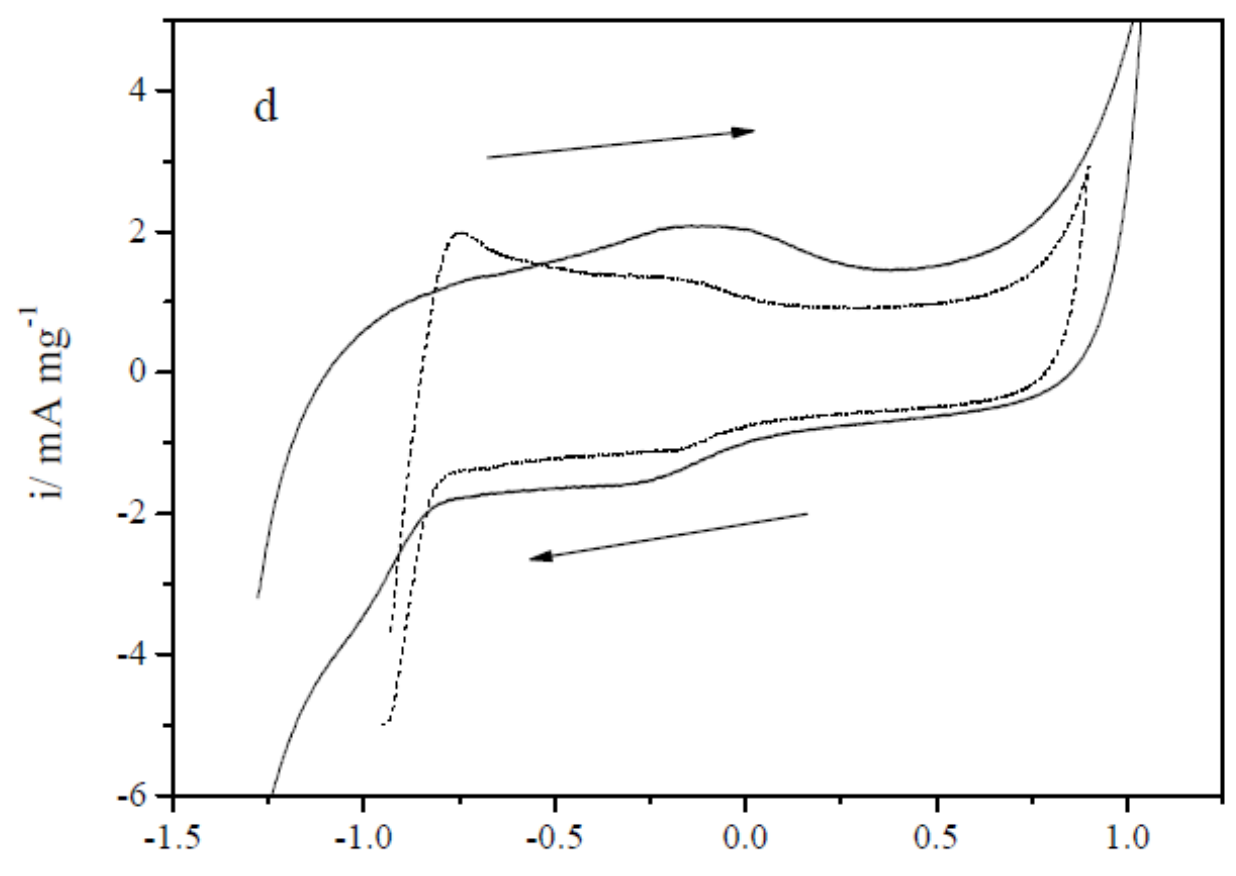

Figure 5.d

E vs. SCE/V

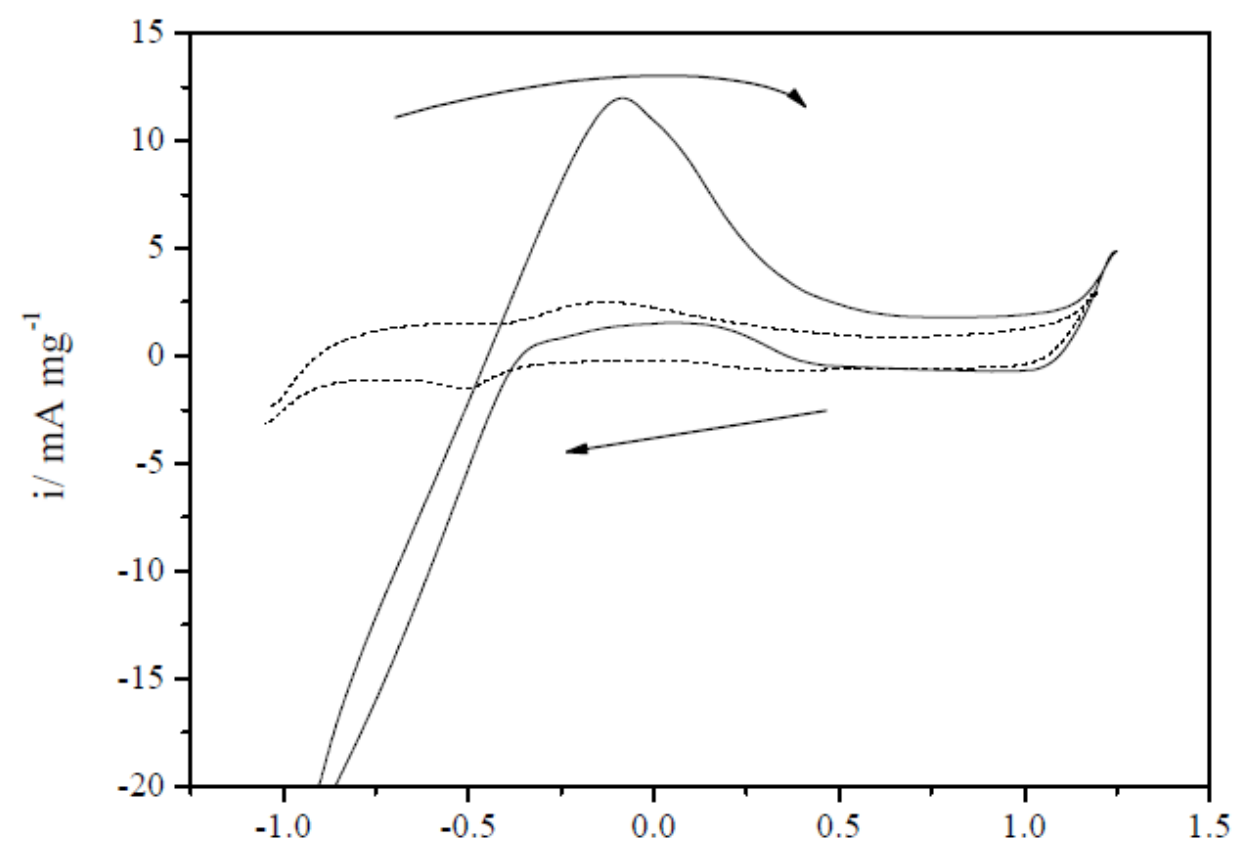

Figure 6

E vs. SCE/V 


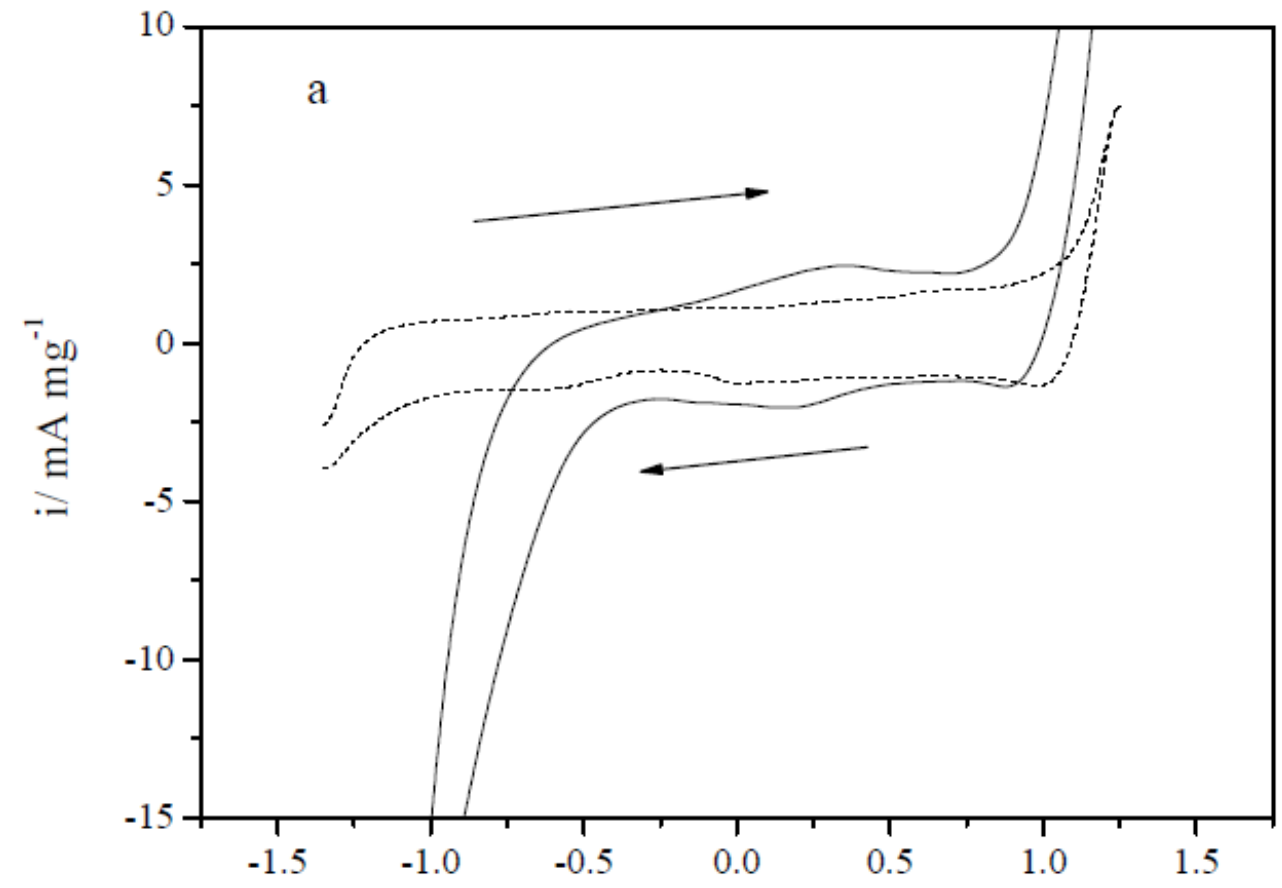

Figure 7.a

E vs. SCE/V

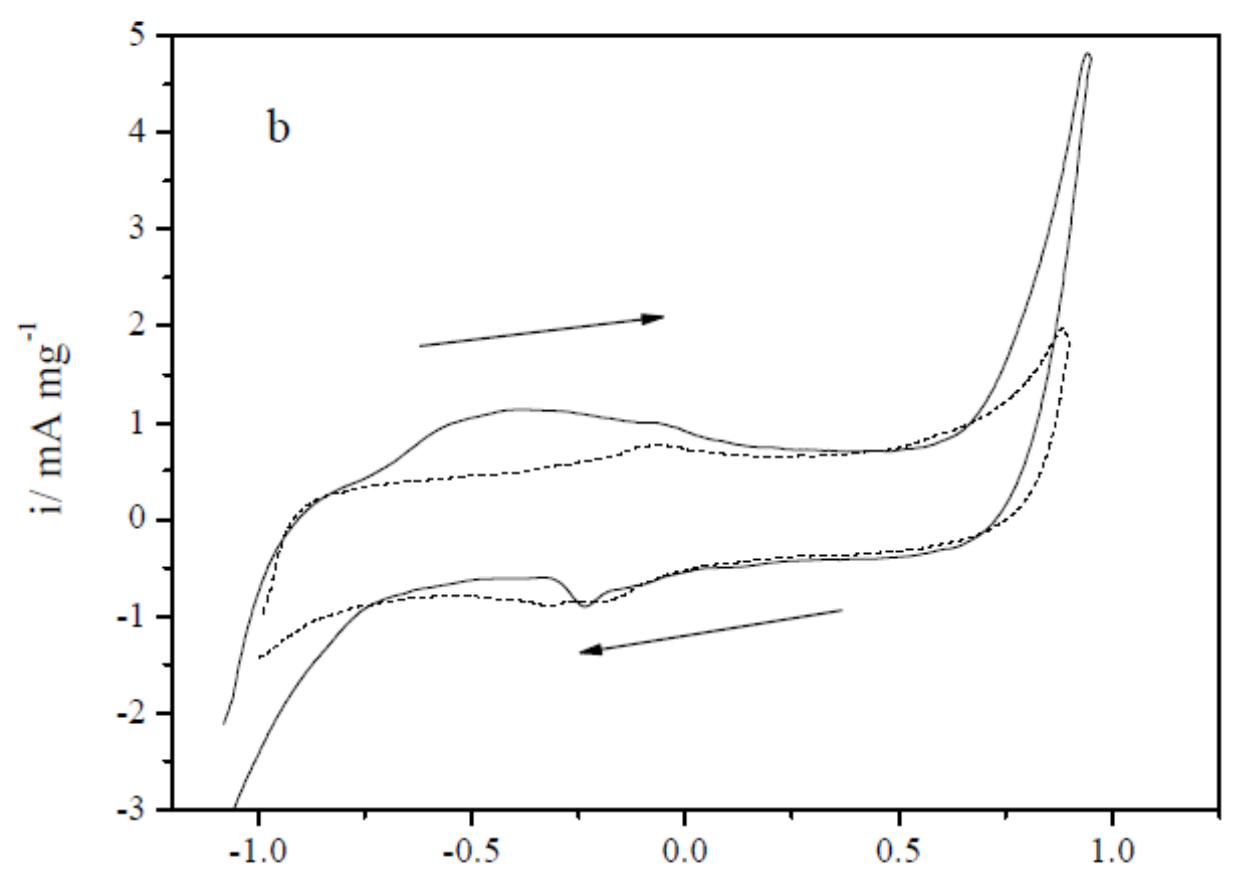

Figure 7.b

E vs. SCE/V 


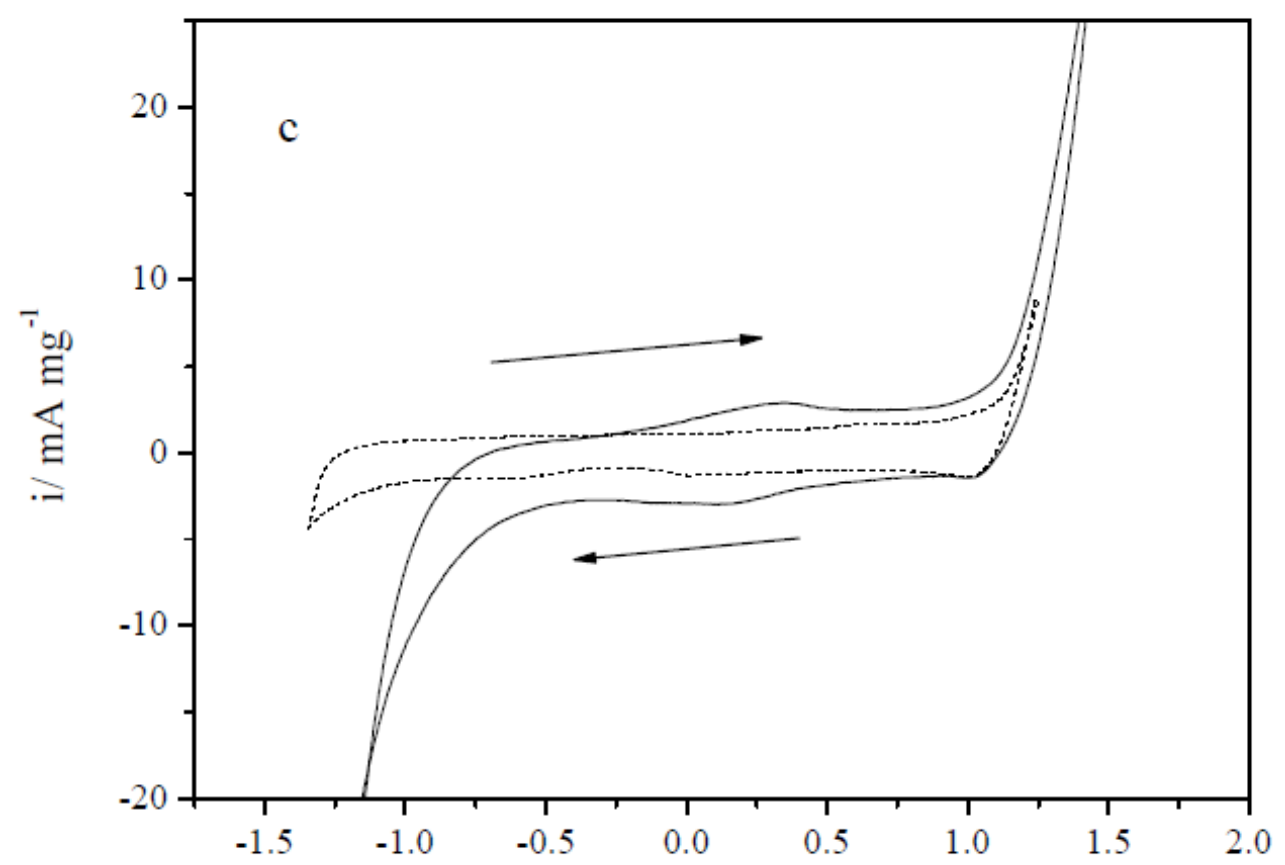

Figure 7.c

E vs. SCE/V

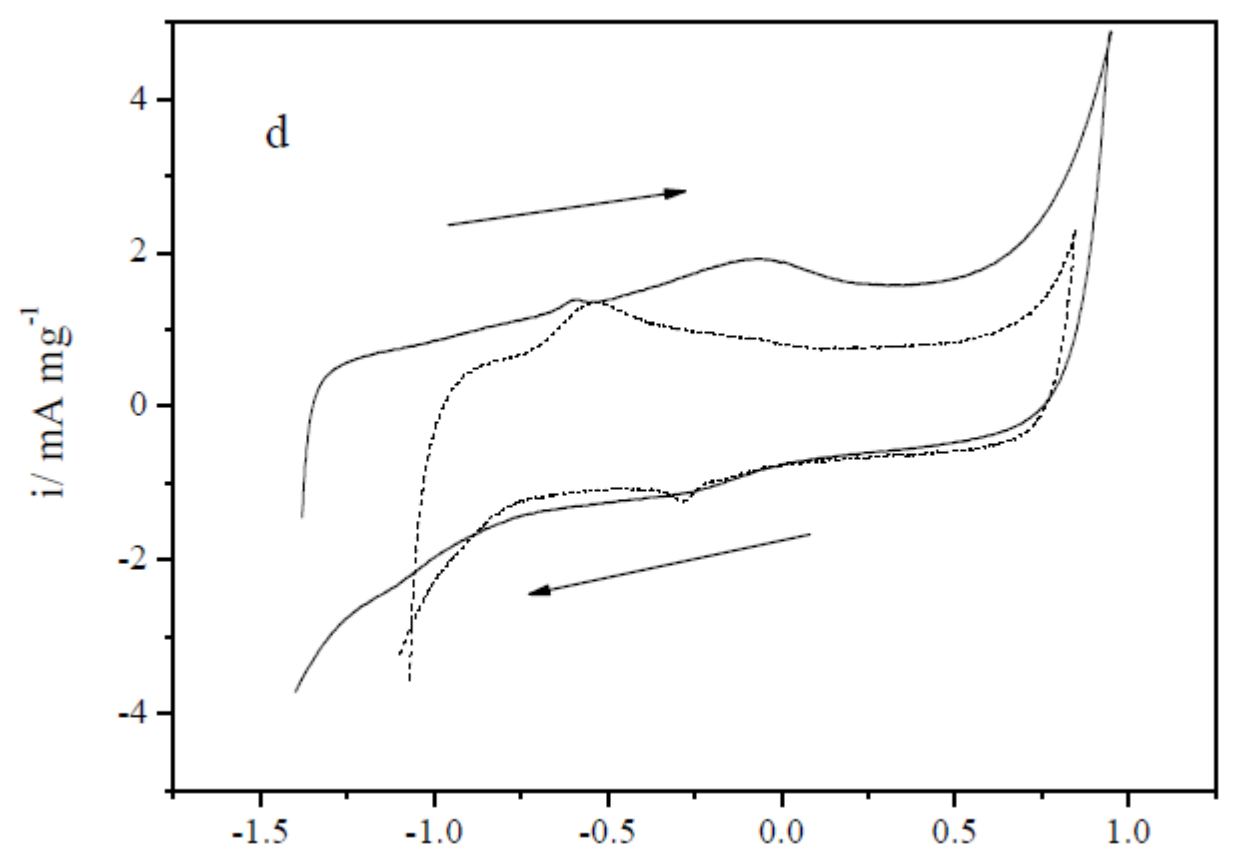

Figure 7.d

E vs. SCE/V 


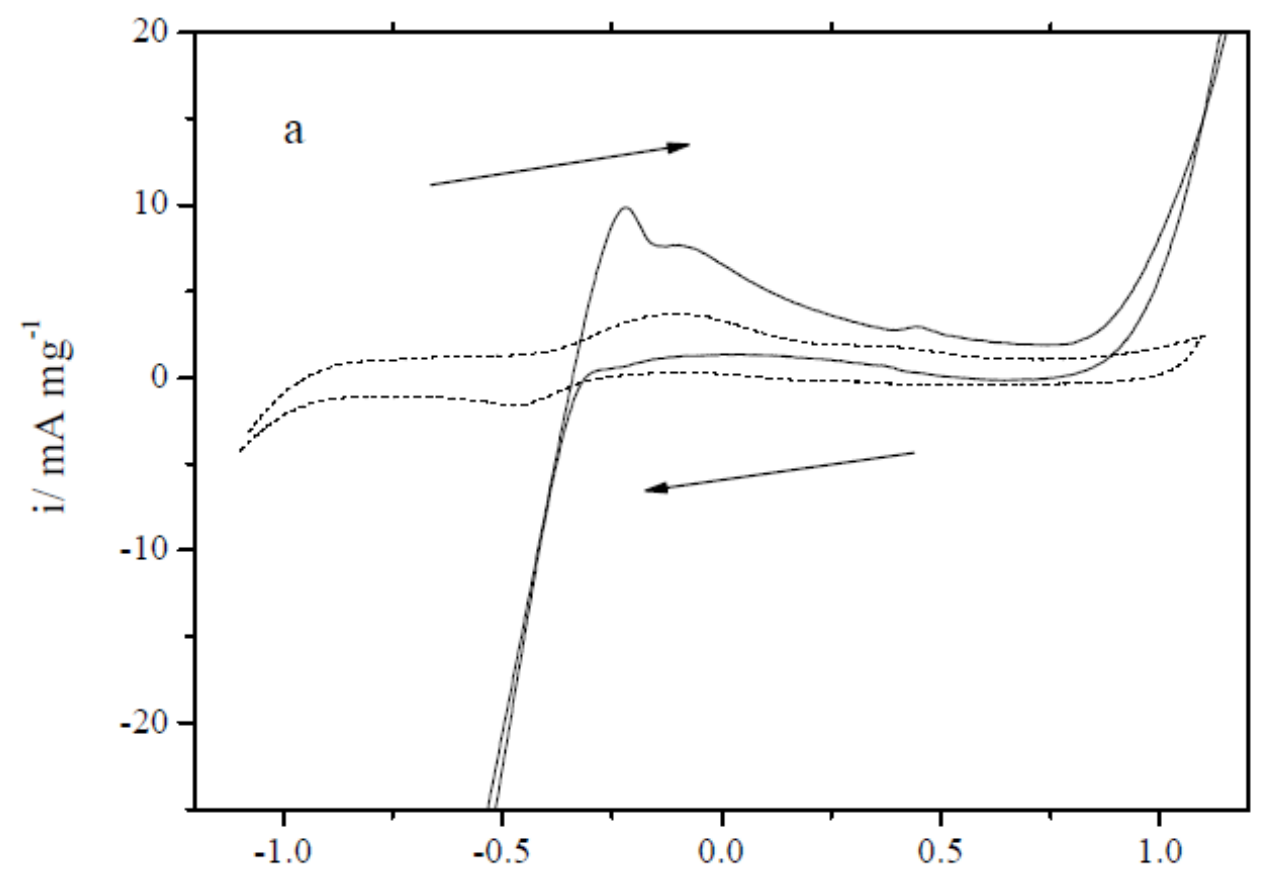

Figure 8.a

E vs. SCE/V

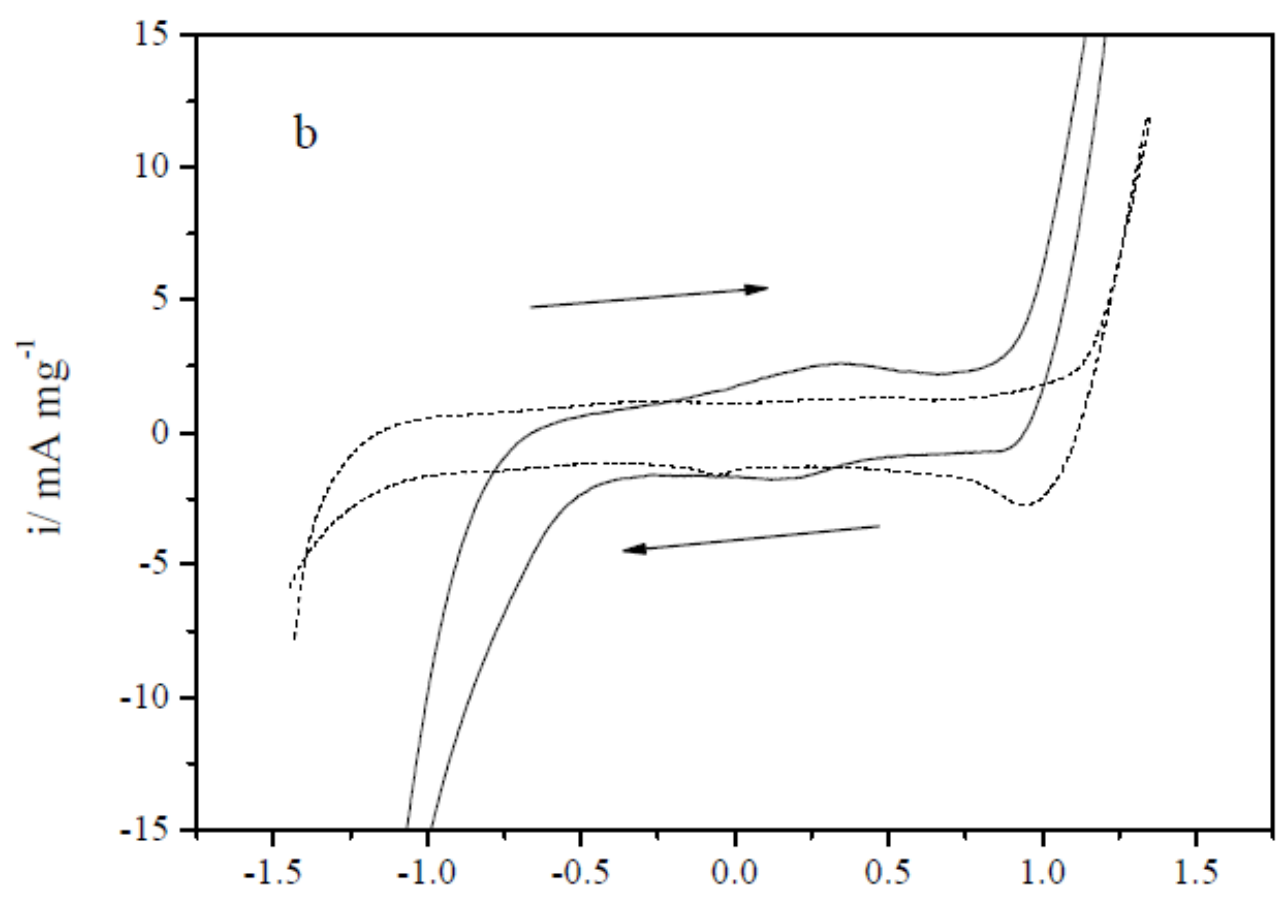

Figure 8.b

E vs. SCE/V 